\title{
Kinetics of Phenol Biodegradation by Heavy Metal Tolerant Rhizobacteria Glutamicibacter nicotianae MSSRFPD35 From Distillery Effluent Contaminated Soils
}

\author{
Purushothaman Duraisamy, Jegan Sekar, Anu D. Arunkumar and \\ Prabavathy V. Ramalingam*
}

Microbiology Lab, Biotechnology Programme, M. S. Swaminathan Research Foundation, Chennai, India

\section{OPEN ACCESS}

Edited by:

Jaco Vangronsveld,

University of Hasselt, Belgium

Reviewed by:

Zofia Piotrowska-Seget, University of Silesia of Katowice,

Poland

Ang Li,

Harbin Institute of Technology, China

*Correspondence: Prabavathy V. Ramalingam prabavathyvr@mssrf.res.in

Specialty section:

This article was submitted to

Microbiotechnology,

a section of the journal

Frontiers in Microbiology

Received: 27 March 2020

Accepted: 17 June 2020

Published: 15 July 2020

Citation:

Purushothaman D, Jegan S, Anu

DA and Prabavathy VR (2020) Kinetics of Phenol Biodegradation by Heavy Metal Tolerant Rhizobacteria

Glutamicibacter nicotianae MSSRFPD35 From Distillery Effluent

Contaminated Soils.

Front. Microbiol. 11:1573. doi: 10.3389/fmicb.2020.01573
Biodegradation of phenol using bacteria is recognized as an efficient, environmentally friendly and cost-effective approach for reducing phenol pollutants compared to the current conventional physicochemical processes adopted. A potential phenol degrading bacterial strain Glutamicibacter nicotianae MSSRFPD35 was isolated and identified from Canna indica rhizosphere grown in distillery effluent contaminated sites. It showed high phenol degrading efficiency up to $1117 \mathrm{mg} \mathrm{L}^{-1}$ within $60 \mathrm{~h}$ by the secretion of catechol 1,2-dioxygenase via ortho intradial pathway. The strain MSSRFPD35 possess both the catechol 1,2 dioxygenase and catechol 2,3 dioxygenase coding genes that drive the ortho and meta pathways, but the enzymatic assay revealed that the strain cleaves catechol via ortho pathway. Haldane's kinetic method was well fit to exponential growth data and the following kinetic parameter was obtained: $\mu^{*}=0.574 \mathrm{~h}^{-1}, K_{\mathrm{i}}=268.1$, $K_{\mathrm{s}}=20.29 \mathrm{mg} \mathrm{L}^{-1}$. The true $\mu_{\max }$ and $S_{\mathrm{m}}$ were calculated as $0.37 \mathrm{~h}^{-1}$ and $73.76 \mathrm{mg}$ $\mathrm{L}^{-1}$, respectively. The Haldane's constant values were similar to earlier studies and healthy fitness depicted in correlation coefficient value $R^{2}$ of 0.98 . Phenol degrading kinetic's was predicted using Haldane's model as $q_{\max } 0.983, K_{i}^{\prime} 517.5$ and $K_{s}{ }^{\prime}$ 9.152. Further, MSSRFPD35 was capable of utilizing different monocyclic and polycyclic aromatic hydrocarbons and to degrade phenol in the presence of different heavy metals. This study for the first time reports high phenol degrading efficiency of $G$. nicotianae MSSRFPD35 in the presence of toxic heavy metals. Thus, the strain G. nicotianae MSSRFPD35 can be exploited for the bioremediation of phenol and its derivatives polluted environments, co-contaminated with heavy metals.

\footnotetext{
Keywords: phenol biodegradation, distillery effluent, Glutamicibacter sp., Canna indica, Haldane's kinetics, heavy metal tolerance, soil microcosm
}

\section{INTRODUCTION}

Phenol and its derivatives namely nitrophenol, halogenated phenol, alkylphenol, etc. are widely used in several industrial plants like petrochemical, phenol resin, pharmaceuticals, paint, textile, leather, pulp mills, coal conversion, and leather processing units (Haddadi and Shavandi, 2013; Jiang et al., 2013; Villegas et al., 2016; Prasse et al., 2018). Gallons of unprocessed effluents polluted 
with phenol and its derivatives discharged by these industries are reported to contaminate soil, groundwater table and agriculture lands; and to harm the soil and plant health and productivity (Shi et al., 2014; Wu et al., 2018) and also to affect terrestrial and aquatic animals, and humans at very low concentrations (Prasse et al., 2018).

Phenolic compounds have a recalcitrant structure, which consists of an aromatic ring with a hydroxyl group attached to the benzene ring; making it resistant to natural biodegradation and decomposition (Reardon et al., 2000; Ma et al., 2013; Chen et al., 2017). Phenol is highly soluble in water up to the concentration of $10 \mathrm{~g} \mathrm{~L}^{-1}$ (Bajaj et al., 2009) and thus the effluents discharged from industries contain high concentrations of phenol and its derivatives in the range of 50-2000 $\mathrm{mg} \mathrm{L}^{-1}$ (Jusoh and Razali, 2008) concentrations much higher than the permissible limits leading to high risk of polluting the environment. The permissible limits of phenol in industrial effluents to be discharged in the domestic surface water is only $1 \mathrm{mg} \mathrm{L}^{-1}$ (IS: 2490-1974) and $5 \mathrm{mg} \mathrm{\textrm {L } ^ { - 1 }}$ in public sewers (IS: 3306-1974) (Hussain et al., 2015) and concentration range of 5-2000 $\mathrm{mg} \mathrm{L}^{-1}$ phenol is reported to be carcinogenic for human and toxic to all life forms (Comte et al., 2013).

In addition to phenol, the effluent released from industries contain heavy metals like copper, lead, cadmium, chromium, etc., as co-contaminants in different composition and concentration which are highly toxic, persistent, and non-degradable in nature (Thavamani et al., 2012; Wong et al., 2015). The continued discharge of phenol and heavy metal contaminated industrial effluents leads to its accumulation in the environment including water bodies that reach a threshold harmful to living systems, and acute phenol exposures causes lung and digestive tract carcinoma, liver, kidney, heart, and nervous system disorders in human, enters the food chain and leads to severe socio-environmental problems (Wang et al., 2011; Fan et al., 2017). Therefore, it is imperative to reduce the concentration of phenol and heavy metals in the industrial effluents and maintain defined standards before releasing these pollutants into the environment.

Although numerous physio-chemical methods such as water chlorination, flocculation, photocatalysis, Fenton's reaction, ozonisation, chemical oxidation, activated carbon adsorption, reverse osmosis, ion exchange with resin, etc., are widely adopted for the removal of phenol and heavy metal contaminants from industrial waste-waters (Mohammadi et al., 2014; Villegas et al., 2016) these approaches are less efficient with high operation cost and produce intermediate compounds as secondary pollutants (Rajasulochana and Preethy, 2016). Therefore biological treatment especially the use of microbial cultures is reported to significantly degrade phenol and its derivatives from different industrial wastewaters, particularly bacterial embedded treatments showed a significant reduction at low cost without secondary pollutants, and is eco-friendly (Banerjee and Ghoshal, 2010b; Wang et al., 2015; Chen et al., 2017; Tiwari et al., 2017).

Several bacterial groups are described to degrade phenol either by anaerobic or aerobic metabolic activity and utilize it as a sole energy source (Thavamani et al., 2012; Wang et al., 2015; Gu, 2016). Phenol degrading bacteria follow either the ortho cleavage pathway which converts catechol into intermediate cis, cis muconic acid or the meta cleavage pathway that converts catechol to 2-hydroxymuconic semialdehyde (2-HMSA) (Hamzah and AlBaharna, 1994; Banerjee and Ghoshal, 2010b; Hasan and Jabeen, 2015; Wu et al., 2018) during phenol degradation. Different phenolic compounds at varying concentrations are reported to trigger either ortho or meta or both the metabolic cleavage pathways involved in phenol degradation (Wu et al., 2018). Pseudomonas cepacia ATCC 29351, when grown on salicylate, activates only the ortho-pathway, while benzoate activates both ortho and meta pathways (Hamzah and Al-Baharna, 1994; Mahiudddin et al., 2012). Pseudomonas putida ATCC 49451 degrades benzoate at $200-300 \mathrm{mg} \mathrm{L}^{-1}$ involving only the ortho pathway, but at higher concentrations of benzoate, the degradation involves both the pathways (Cao et al., 2008). Bacterial degradation of phenol and its derivatives like benzene and toluene had been inferred and extensively studied in different groups such as Pseudomonas sp. (Reardon et al., 2000; Mahiudddin et al., 2012; Hasan and Jabeen, 2015; Chen et al., 2017; Iqbal et al., 2018), Burkholderia sp. (Arora and Jain, 2012), Kocuria sp. (Wu et al., 2018), Acinetobacter sp. (Jiang et al., 2013; Iqbal et al., 2018), Arthrobacter sp. (Wong et al., 2015), Bacillus sp. (Banerjee and Ghoshal, 2010b; Hasan and Jabeen, 2015; Iqbal et al., 2018), Halomonas sp. (Haddadi and Shavandi, 2013), Arthrobacter sp. W1, etc. (Ma et al., 2013; Shi et al., 2014; Wong et al., 2015).

Degradation kinetics of microbial bioremediation in bioreactor offers evidence for optimum design and efficient bioremediation of phenol contaminated effluents (Banerjee and Ghoshal, 2010b). Generally, the derivatives of phenol and other co-contaminants such as heavy metals discharged from industries pose great challenge for efficient biodegradation and also depends on the tolerance level of the degrading bacterial isolates as these toxic substances negatively correlate with the degradation efficacy (Thavamani et al., 2012; Mohammadi et al., 2014; Satchanska et al., 2015; Wong et al., 2015; Chen et al., 2017; Iqbal et al., 2018). However, only few studies have reported microbial degradation of phenol particularly at high concentrations (i.e.) up to $1100 \mathrm{mg} \mathrm{L}^{-1}$, and limited studies have reported the biological degradation efficiency of phenol under the influence of different heavy metals such as chromium, etc., till date (Lima et al., 2008; Ontanon et al., 2015; Wong et al., 2015). Moreover, few studies have been carried out to assess the phenol degrading efficiency of bacteria isolated from distillery effluent contaminated Canna indica rhizosphere associated soil and to estimate the impact of heavy metals on the rate of phenol degradation. Hence exploration of strains with the capability to degrade phenol with high efficiency and with tolerance to multiple heavy metals can be promising candidates for the bioremediation of phenol contaminated effluents co contaminated with heavy metals which have inhibitory effects on bacterial degradation. So, this study aims (i) to isolate and characterize potential phenol degrading bacterial isolates, (ii) to evaluate kinetic models to determine the degradation efficiency of potential isolates, (iii) to identify molecular and metabolic pathways involved in the degradation of phenol, and (iv) to determine the impact of heavy metals pollutants in phenol biodegradation. 


\section{MATERIALS AND METHODS}

\section{Materials and Chemicals}

Davis minimal medium (DMM), 4-aminoantipyrine, potassium ferrocyanide, catechol, sodium hydroxide pellets used in this study were purchased from HiMedia Laboratories Pvt. Ltd. Mumbai, phenol, 2-mercaptoethanol, ammonium hydroxide, glycerol, disodium EDTA, primers, acids and solvents were procured from Sigma, Aldrich, Tris Base, Agarose from Bio Basic Inc. All the following heavy metals $\mathrm{CoCl}_{2} .2 \mathrm{H}_{2} \mathrm{O}, \mathrm{ZnSO}_{4} \cdot \mathrm{H}_{2} \mathrm{O},\left(\mathrm{CH}_{3} \mathrm{COO}\right)_{2} \mathrm{~Pb} .3 \mathrm{H}_{2} \mathrm{O}, \mathrm{HgCl}_{2}, \mathrm{CdCl}_{2}$, $\mathrm{CuSO}_{4} .5 \mathrm{H}_{2} \mathrm{O}, \mathrm{NiCl}_{2} .6 \mathrm{H}_{2} \mathrm{O}, \mathrm{MnCl}_{2} .4 \mathrm{H}_{2} \mathrm{O}$, and $\mathrm{K}_{2} \mathrm{Cr}_{2} \mathrm{O}_{7}$ were purchased from Merck Millipore, Taq DNA polymerase Master Mix from Ampliqon and PCR purification Kit from Favorgen Biotech Corp. were used.

\section{Isolation of Bacteria From Rhizosphere Soil}

Phenol degrading bacterial strains were isolated from rhizosphere soils of Canna indica grown in sites contaminated by effluents from Distillery plant located in Vuyyuru, Krishna District, Andhra Pradesh, India $\left(16^{\circ} 21^{\prime} 52.7^{\prime \prime} \mathrm{N} 80^{\circ} 51^{\prime} 52.2^{\prime \prime} \mathrm{E}\right)$. Three individual $C$. indica plants were uprooted and the rhizosphere soils from each sample were collected aseptically in sterile polythene bags and pooled. About $10 \mathrm{~g}$ of rhizosphere soil was used for the isolation of phenol degrading bacterial isolates by aseptically dispensing it into $100 \mathrm{ml}$ of DMM containing dipotassium phosphate $\left(7 \mathrm{~g} \mathrm{~L}^{-1}\right)$, monopotassium phosphate $(2 \mathrm{~g}$ $\left.\mathrm{L}^{-1}\right)$, ammonium sulfate $\left(1 \mathrm{~g} \mathrm{~L}^{-1}\right)$, sodium citrate $\left(0.5 \mathrm{~g} \mathrm{~L}^{-1}\right)$ and magnesium sulfate $\left(0.1 \mathrm{~g} \mathrm{~L}^{-1}\right)$ with final $\mathrm{pH} 7.0$ supplemented with $200 \mathrm{mg} \mathrm{L}^{-1}$ of phenol and enriched by incubating in the shaker at $160 \mathrm{rpm}$ at $30^{\circ} \mathrm{C}$ for $24 \mathrm{~h}$. Then $1 \mathrm{ml}$ of the enriched soil suspension sample was serially diluted and spread on DMM plate amended with $200 \mathrm{mg} \mathrm{L}^{-1}$ of phenol as the sole source of carbon with $1.8 \%$ agar and incubated for $48 \mathrm{~h}$ at $30^{\circ} \mathrm{C}$ and the colonyforming units (CFU) were counted. Diverse individual colonies were selected and streaked in $200 \mathrm{mg} \mathrm{L}^{-1}$ phenol amended DMM medium and stored in $25 \%$ glycerol $(\mathrm{v} / \mathrm{v})$ at $-80^{\circ} \mathrm{C}$ for further analysis.

\section{Screening for Potential Phenol Degrading Strains}

The bacteria isolates obtained from the DMM medium amended with $200 \mathrm{mg} \mathrm{L}^{-1}$ of phenol were screened to determine the phenol degrading efficiency by inoculating in DMM agar plates amended with different phenol concentration of $600,700,800$, 900,1000 , and $1200 \mathrm{mg} \mathrm{L}^{-1}$. The inoculated plates were incubated at $30^{\circ} \mathrm{C}$ for $72 \mathrm{~h}$ and the isolates with efficiency to grow in phenol concentration of $1200 \mathrm{mg} \mathrm{L}^{-1}$ were selected and maintained as pure culture (Sandhu et al., 2009).

\section{DNA Fingerprinting Analysis}

Genomic DNA was isolated from efficient bacterial isolates capable of growing in $1000 \mathrm{mg} \mathrm{L}^{-1}$ of phenol and the diversity was analyzed using BOXA1R primer (5'-ACG GCA AGG CGA CGC TGA CG-3') (Viswanath et al., 2015). Each $20 \mu$ l reaction containing $6 \mu \mathrm{l}$ of $2 \mathrm{X}$ ampliqon red mix, $2 \mu \mathrm{l}$ of $2.5 \mathrm{pmol}$ primer, $2 \mu \mathrm{l}$ of $50 \mathrm{ng}$ template DNA was made up to $20 \mu \mathrm{l}$ using double sterilized HPLC water. The PCR was carried by, initial denaturation at $94^{\circ} \mathrm{C}$ for $5 \mathrm{~min}, 35$ cycles of $94^{\circ} \mathrm{C}$ for $3 \mathrm{~s}, 92^{\circ} \mathrm{C}$ for $30 \mathrm{~s}$, annealing at $50^{\circ} \mathrm{C}$ for $1 \mathrm{~min}$, extension at $68^{\circ} \mathrm{C}$ for $8 \mathrm{~min}$, followed by final extension for $10 \mathrm{~min}$ then hold at $4^{\circ} \mathrm{C}$. Around $20 \mu \mathrm{l}$ of PCR products were electrophoresed for $6 \mathrm{~h}$ on $2 \%$ agarose gel prepared in $1 \mathrm{X}$ TAE buffer. The BOX-PCR DNA profiles were visualized under UV illumination and documented using a Gel Doc ${ }^{\mathrm{TM}} \mathrm{XR}+$ Gel Documentation System (Bio-Rad, United States). The fingerprinting profiles were analyzed using GelJv.2 DNA tool by normalization, recognition, and assignment of bands on the gel by the Dice coefficient (Heras et al., 2015). The cluster analysis was performed by unweighted pair group method with arithmetic mean (UPGMA) algorithm and the dendrogram was constructed with similarity matrices.

\section{S rRNA Based Identification of the Phenol Degrading Bacterial Isolates}

The 16S rRNA gene was amplified from the representative isolates of the BOX-PCR cluster groups using universal primers $27 \mathrm{~F}\left(5^{\prime}-\right.$ AGA GTT TGA TCM TGG CTC AG-3') and 1492R (5'-TAC GGH TAC CTT GTT ACG ACT T-3') (Sekar et al., 2018). Each $20 \mu \mathrm{l}$ reaction containing $6 \mu \mathrm{l}$ of $2 \mathrm{X}$ ampliqon red mix, $2 \mu \mathrm{l}$ of $2.5 \mathrm{pmol} 27 \mathrm{~F}$ and $1492 \mathrm{R}$ primers, $2 \mu \mathrm{l}$ of $50 \mathrm{ng}$ template DNA was made up to $20 \mu \mathrm{l}$ using double sterilized HPLC water. The PCR conditions were as follows, initial denaturation $94^{\circ} \mathrm{C}$ for $5 \mathrm{~min}, 35$ cycles of $94^{\circ} \mathrm{C}$ for $1 \mathrm{~min}, 55^{\circ} \mathrm{C}$ for $1 \mathrm{~min}$ and $68^{\circ} \mathrm{C}$ for $8 \mathrm{~min}$. followed by final extension for $10 \mathrm{~min}$ then hold at $4^{\circ} \mathrm{C}$. PCR products were electrophoresed on $1 \%$ agarose gel in $1 \mathrm{X}$ TAE buffer at $100 \mathrm{~V}$ for $30 \mathrm{~min}$ and amplified PCR products were purified using the FavorPrep GEL/PCR Purification Kit (Taiwan) and were sequenced. The taxonomic position of the isolates were identified by sequence similarity blast search against EzTaxon sequence database (Kim et al., 2012). The 16S rRNA phylogenetic tree was constructed using a neighbor-joining algorithm and confidence level in nodes were determined using 1000 bootstrap resampling conducted using the MEGA v6 (Kumar et al., 2016).

\section{Determination of Growth, Phenol Degradation, and Quantification of Substrate}

The growth and phenol degrading efficiency of representative isolates from each cluster groups of BOX profiles were determined in DMM broth with $1000 \mathrm{mg} \mathrm{L}^{-1}$ phenol. The culture inoculated broths were incubated in $30^{\circ} \mathrm{C}$ at $160 \mathrm{rpm}$ for $96 \mathrm{~h}$, the sample were withdrawn at every $24 \mathrm{~h}$ and analyzed for phenol concentration. A $1 \mathrm{ml}$ of culture was centrifuged at $8000 \mathrm{rpm}$ for $10 \mathrm{~min}$ to remove the cell debris and $50 \mu \mathrm{l}$ of supernatant was made up to $1 \mathrm{ml}$ and used to determine the phenol residual content through modified 4-amino antipyrine method at absorbance $510 \mathrm{~nm}$ by adding $25 \mu \mathrm{l}$ of $0.5 \mathrm{~N}$ $\mathrm{NH}_{4} \mathrm{OH}$ to sample, followed by $15 \mu \mathrm{l}$ of PBS (pH-6.9), $11 \mu \mathrm{l}$ of 4-aminoantipyrine, and $11 \mu \mathrm{l}$ of potassium ferrocyanide and incubated at $30^{\circ} \mathrm{C}$ room temperature for $15 \mathrm{~min}$. The appearance of dark red color indicated positive reaction and intensity was 
measured using Multiskan ${ }^{\mathrm{TM}}$ GO Microplate Spectrophotometer at $500 \mathrm{~nm}$ (APHA, 2017). Phenol standard was prepared with the concentration range of $100 \mathrm{mg} \mathrm{L}^{-1}-1200 \mathrm{mg} \mathrm{L}^{-1}$, linear equation $Y=0.002447^{*} X+0.1423$ was obtained and used to determine phenol concentration of unknown samples (Supplementary Figure S1).

\section{Assessment of Growth Rate and Phenol Degradation Kinetics of MSSRFPD35}

The biodegradation of phenol by a potential isolate MSSRFPD35 was determined in batch mode in $250 \mathrm{ml}$ Erlenmeyer flask containing $95 \mathrm{ml}$ of DMM with initial phenol concentration ranging from 0 to $1117 \mathrm{mg} \mathrm{L}^{-1}$. A 5\% inoculum of MSSRFPD35 $\left(8 \log\right.$ CFU ml $\mathrm{ml}^{-1}$ ) grown in DMM broth with phenol $(200 \mathrm{mg}$ $\mathrm{L}^{-1}$ ) was inoculated in DMM medium amended with phenol concentrations of 0 to $1117 \mathrm{mg} \mathrm{L}^{-1}$, flask without inoculation served as controls and the assay was performed in triplicates. The inoculated flasks were incubated on a rotary shaker at $160 \mathrm{rpm}$ for $120 \mathrm{~h}$ at $30^{\circ} \mathrm{C}$. At every $12 \mathrm{~h}$ time interval samples were withdrawn from each conical flask and the growth rate was measured as absorbance at $600 \mathrm{~nm}$ using Multiskan ${ }^{\mathrm{TM}} \mathrm{GO}$ Microplate Spectrophotometer (APHA, 2017).

\section{Cell Growth Rate Kinetics}

The growth absorbance of MSSRFPD35 was converted into dry biomass using linear coefficient derived from growth absorbance vs. dry biomass $(X)$, the cell growth was follows first-order kinetics.

$$
\begin{aligned}
\frac{d X}{d t} & =\mu X \\
d X / X & =\mu d t
\end{aligned}
$$

when integrating Eq. (2) with limit $t_{0}$ (initial time) to $t$ (a time when maximum biomass reached), it becomes

$$
\ln X-\ln X_{0}=\mu\left(t_{0}-t\right)
$$

where $X_{0}$ - initial biomass, $X$ - biomass at time $t$, and Eq. (3) rewritten as

$$
\mu=\ln \left(X_{0} / X\right) / \Delta t
$$

The experimental specific growth rate $(\mu)$ was calculated from the slope of a semi-logarithmic plot of dry biomass $\ln \left(X / X_{0}\right)$ vs. time.

The growth rate of microbes on inhibitory substrates such as phenol is often described using the substrate inhibition model especially the Haldane's kinetic model Eq. (5)

$$
\mu=\frac{\mu^{*} S}{K_{s}+S+\left(S^{2} / K_{i}\right)}
$$

Experimental $\mu$ was calculated for each initial phenol concentration and this $\mu$ value against different initial phenol concentration $\left(S_{0}\right)$ was used to predict various kinetic parameters of Haldane's kinetic model using non-linear regression analysis.

Here $\mu^{*}$ is one of the fitting parameters of the Haldane model, the true $\mu_{\max }$ occurs when $d \mu / d S=0$;

$$
S_{m}=\sqrt{K_{s} K_{i}}
$$

Replacing Eq. (6) in Eq. (5), (Christen et al., 2012).

$$
\mu_{\max }=\frac{\mu^{*}}{1+2 \sqrt{K_{s} / K_{i}}}
$$

Where $\mu_{\max }$ is true maximum growth rate, calculated from Eq. (7).

\section{Degradation Kinetics}

The phenol degradation rate from each sample was estimated by using 4-aminoantipyrine method as described above (APHA, 2017). Reduction of phenol content is non-linear concerning time, first-order kinetics was adopted for degradation.

$$
\begin{gathered}
\frac{d S}{d t}=-q S \\
d S / S=-q d t
\end{gathered}
$$

Integrate Eq. (9) with time $t_{0}$ to $t$ (when complete depletion of phenol)

$$
\ln S_{0}-\ln S=-q\left(t_{0}-t\right)
$$

where $S_{0}$ - initial phenol concentration, $S$ - phenol concentration at time $t$.

$$
q=\ln \left(S / S_{0}\right) / \Delta t
$$

To determine the degradation rate $(q)$ initial phenol concentration $\left(S_{0}\right)$ was acquired from the slope of the linear curve by plotting between $-\ln \left(S / S_{0}\right)$ and time. The phenol degradation kinetics was acquired by experimental degradation rate of individual phenol concentration (Banerjee and Ghoshal, 2010b; Satchanska et al., 2015). To predict the coefficient values, Haldane's inhibitory model was used (Eq. 12),

$$
q=\frac{q^{*} S}{K_{s}^{\prime}+S+S^{2} / K_{i}^{\prime}}
$$

Where $K_{\mathrm{s}}{ }^{\prime}$ saturation constant, $K_{\mathrm{i}}{ }^{\prime}$ Inhibition constant, $S$ substrate conc. at time $t$.

\section{Molecular Metabolic Pathway Identification}

The degradative enzymes involved in phenol degradation was assessed by targeting the genes coding for catechol 1,2-dioxygenase (CBT77506) and catechol 2,3-dioxygenase (PJJ43550). The nucleotide sequences of these enzymes from Glutamicibacter spp. were extracted from the European 
Nucleotide Archives (ENA). Primers were designed for catechol 1,2-dioxygenase gene between $321 \mathrm{bp}$ and $730 \mathrm{bp}$ AC12O-F (5'-ATC GAA GGC CCT TAC TAC-3'); AC12O-R (5'-AAG TAC AGC TGG GCG GTG A-3') and for catechol 2,3-dioxygenase between 3 bp to 819 bp AC23O-F (5'-GAG CAA AGA GAT CGC AAA CC-3'); AC23O-R (5' -GTA GAT CTC GAT GCG GTG GT$3^{\prime}$ ) using Primer3Plus program (Untergasser et al., 2012). PCR was carried out in a Bio-Rad thermal cycler with $20 \mu \mathrm{l}$ of reaction mixture containing $2.5 \mathrm{pmol}$ of each forward and reverse primer, $\sim 50$ ng of DNA template, $1 \mathrm{X}$ Ampliqon Taq DNA Polymerase Master Mix RED, and the amplification conditions were as follows, an initial denaturation for $5 \mathrm{~min}$ at $94^{\circ} \mathrm{C}$, followed by 35 cycles at $94^{\circ} \mathrm{C}$ for $1 \mathrm{~min}, 56^{\circ} \mathrm{C}$ for $1 \mathrm{~min}$ and $72^{\circ} \mathrm{C}$ for $1 \mathrm{~min}$, with a final extension at $72^{\circ} \mathrm{C}$ for $10 \mathrm{~min} .5 \mu \mathrm{l}$ of the PCR product from each sample was electrophoresed using $1 \%(\mathrm{w} / \mathrm{v})$ agarose gel with $100 \mathrm{bp}$ marker (Thermo, India) and later purified using FavorPrep GEL/PCR Purification Kit (Taiwan). The purified products were sequenced using capillary electrophoresis on an ABI 310 Genetic Analyzer (Applied Biosystems). The identities of the sequenced fragments were determined through BLASTN analysis and CLUSTALW alignment was performed using similarity sequences and the phylogenetic relationship was determined using the neighbor-joining method, with bootstrap analysis (1000 data sets) through Molecular Evolutionary Genetics Analysis (MEGA 6) (Kumar et al., 2016).

\section{Detection of Enzymatic Cleavage Pathway Involved in Phenol Degradation}

The strain MSSRFPD35 was inoculated in DMM medium containing $1000 \mathrm{mg} \mathrm{L}^{-1}$ of phenol and harvested at late exponential phase $(48 \mathrm{~h})$ by centrifugation at $8000 \mathrm{rpm}$ at $4^{\circ} \mathrm{C}$ for $10 \mathrm{~min}$. The bacterial cells were washed and resuspended in Tris-HCl buffer ( $\mathrm{pH}$ 7.6) and kept in ice to avoid heat generation during sonication for $4 \mathrm{~min}$ ( 1 or $2 \mathrm{~min}$ off) and to achieve complete lysis. The intracellular crude enzyme present in supernatant were separated from cell debris by centrifugation at $8000 \mathrm{rpm} 4^{\circ} \mathrm{C}$ for $10 \mathrm{~min}$ and the cell-free extracts were stored at $-20^{\circ} \mathrm{C}$. Catechol 1,2-dioxygenase (Ortho enzymatic cleavage assay) and catechol 2,3-dioxygenase (Meta enzymatic cleavage assay) enzyme activities were spectrophotometrically determined using $3.5 \mathrm{ml}$ of quartz cuvette as described by Feist and Hegeman (1969).

The enzymatic assay for Ortho cleavage pathway was performed using $0.7 \mathrm{ml}$ of distilled water, $2 \mathrm{ml}$ of $50 \mathrm{mM}$ Tris-HCL, $0.1 \mathrm{ml}$ of $100 \mathrm{mM} \beta$-mercaptoethanol, $0.1 \mathrm{ml}$ of $1 \mathrm{mM}$ catechol and $0.1 \mathrm{ml}$ of cell-free extract. The formation of aromatic ring cleavage product cis, cis muconic acid was measured spectrophotometrically at an absorbance of $260 \mathrm{~nm}$. Similarly, the enzymatic assay for meta cleavage pathway was carried out using $0.6 \mathrm{ml}$ of distilled water, $2 \mathrm{ml}$ of $50 \mathrm{mM}$ Tris$\mathrm{HCl}, 0.2 \mathrm{ml}$ of $100 \mathrm{mM}$ catechol and $0.2 \mathrm{ml}$ of cell-free extract mixed well and the increase in absorbance was measured at $375 \mathrm{~nm}$ for $5 \mathrm{~min}$. The formation of 2-HMSA from catechol indicates the presence of catechol 2,3-dioxygenase activity at an absorbance of $375 \mathrm{~nm}$. Enzyme activity and specific activities were calculated by equation described by Bhardwaj et al. (2015).

\section{Heavy Metal Tolerance Assay}

Heavy metal tolerance and phenol degradation potential of MSSRFPD35 were determined using manganese (II) $\mathrm{MnCl}_{2} .4 \mathrm{H}_{2} \mathrm{O}-800 \mathrm{mg} \mathrm{L}^{-1}$; iron (II) $\mathrm{FeSO}_{4}-400 \mathrm{mg} \mathrm{L}^{-1}$; Zinc (II) $\mathrm{ZnSO}_{4} \cdot \mathrm{H}_{2} \mathrm{O}-600 \mathrm{mg} \mathrm{L}^{-1}$; lead (II) $\left(\mathrm{CH}_{3} \mathrm{COO}\right)_{2} \mathrm{~Pb} .3 \mathrm{H}_{2} \mathrm{O}-$ $200 \mathrm{mg} \mathrm{L}^{-1}$; cadmium (II) $\mathrm{CdCl}_{2}-50 \mathrm{mg} \mathrm{L}^{-1}$; chromium (VI) $\mathrm{K}_{2} \mathrm{Cr}_{2} \mathrm{O}_{7}-50 \mathrm{mg} \mathrm{L}^{-1}$; nickel (II) $\mathrm{NiCl}_{2} \cdot 6 \mathrm{H}_{2} \mathrm{O}-20 \mathrm{mg} \mathrm{L}^{-1}$; copper (II) $\mathrm{CuSO}_{4} .5 \mathrm{H}_{2} \mathrm{O}-20 \mathrm{mg} \mathrm{L}^{-1}$; cobalt (II) $\mathrm{CoCl}_{2} .2 \mathrm{H}_{2} \mathrm{O}-$ $10 \mathrm{mg} \mathrm{L}^{-1}$; and mercury (II) $\mathrm{HgCl}_{2}-10 \mathrm{mg} \mathrm{L}^{-1}$ in $\mathrm{DMM}$ medium with $1000 \mathrm{mg} \mathrm{L}^{-1}$ of phenol. The flasks were inoculated with 5\% inoculum of $G$. nicotianae MSSRFPD35 (8 log CFU $\mathrm{ml}^{-1}$ ) and incubated on a rotary shaker at $160 \mathrm{rpm}$ for $72 \mathrm{~h}$ at $30^{\circ} \mathrm{C}$. DMM medium without heavy metals and inoculation were maintained as control and all the treatments were performed in triplicates. The samples from flasks were collected at every $24 \mathrm{~h}$ intervals and phenol concentration was measured.

\section{Growth on Different Aromatic Substrates}

Growth of MSSRFPD35 in different phenol derivatives like tannic acid $50 \mathrm{mg} \mathrm{L}^{-1}$; cinnamic acid $100 \mathrm{mg} \mathrm{L}^{-1}$; 1-chloro-2,4-dinitro benzene $50 \mathrm{mg} \mathrm{L}^{-1}$; 4-nitrophenol $50 \mathrm{mg} \mathrm{L}^{-1}$; catechol $100 \mathrm{mg}$ $\mathrm{L}^{-1}$; 1-naphthol $50 \mathrm{mg} \mathrm{L}^{-1}$; naphthylamine $50 \mathrm{mg} \mathrm{L}^{-1}$; and gallic acid $200 \mathrm{mg} \mathrm{L}^{-1}$ was screened by inoculating $5 \%$ inoculum (8 $\log$ CFU/ml) of MSSRFPD35 in DMM broth containing phenol derivatives at the above-mentioned concentration and incubated at $30^{\circ} \mathrm{C}$ on a rotary shaker at $160 \mathrm{rpm}$. Bacterial growth was measured at $600 \mathrm{~nm}$ absorbance (Multiskan ${ }^{\mathrm{TM}} \mathrm{GO}$, Thermo Scientific) after $72 \mathrm{~h}$ of incubation. Individual derivatives in DMM without inoculum served as negative control and were performed in triplicates.

\section{Microcosm Study}

Microcosms were set up by adding $50 \mathrm{~g}$ of soil in $250 \mathrm{ml}$ conical flask and sterilized with three cycles of autoclaving. A uniform volume of $17.5 \mathrm{ml}$ at different concentrations $\left(65 \mathrm{mg} \mathrm{L}^{-1}\right.$, $110 \mathrm{mg} \mathrm{L}^{-1}$ and $240 \mathrm{mg} \mathrm{L}^{-1}$ ) of phenol in sterile distilled water and $2.5 \mathrm{ml}$ inoculum with $8 \log _{10} \mathrm{CFU} \mathrm{m} l^{-1}$ of $\mathrm{G}$. nicotianae MSSRFPD35 were added into the respective flask under aseptic condition and mixed thoroughly to get a uniform suspension of soil, phenol, and the inoculum. The treatments without microbial inoculum served as control and were performed in triplicates. The flasks were kept in $30^{\circ} \mathrm{C}$ for 10 days with gentle mixing at every $24 \mathrm{~h}$. About $500 \mathrm{mg}$ of soil samples were collected at the time of inoculation and on the 10th day of incubation from each treatment and suspended in $500 \mu l$ of distilled water, vigorously mixed and phenol was extracted by collecting the aqueous phase of the mixture and the phenol concentration was determined from the extracted samples as described above (APHA, 2017).

\section{Statistical Analysis}

All experiments were performed in triplicates, regression analysis and kinetics methodology were done using GraphPad Prism 6 . The analytical results were compared by applying a oneway ANOVA and significant differences among treatments were determined by Student's $t$-test. 


\section{Strains and Gene Sequences Submission}

The isolated strains from this study were submitted to M. S. Swaminathan Research Foundation Culture Collection [WDCM Registered Number (1220) and accession are provided, MSSRFPD35 = MSSRFCC1542]. The gene sequences from this study were submitted to GenBank/EMBL and the accession numbers for the 16S rRNA gene of the phenol degrading bacterial are KY849351, KY849352, KX901882 - KX901885, catechol 1,2dioxygenase gene - MK656957 and catechol 2,3-dioxygenase gene - MK656958.

\section{RESULTS}

\section{Isolation and DNA Fingerprinting of Phenol Degrading Bacteria}

The enriched Canna indica rhizosphere soil suspension spread plated on DMM agar medium amended with $200 \mathrm{mg} \mathrm{L}^{-1}$ of phenol yielded $7.3 \log _{10} \mathrm{CFU} \mathrm{ml} \mathrm{m}^{-1}$ after $48 \mathrm{~h}$ of incubation at $30^{\circ} \mathrm{C}$. Around 128 different morphotype bacterial colonies were isolated and the phenol tolerance assay revealed that 11 isolates which were the most dominant colonies could grow in $1000 \mathrm{mg}$ $\mathrm{L}^{-1}$ of phenol concentration and were coded as MSSRFPD27, MSSRFPD28, MSSRFPD29, MSSRFPD30, MSSRFPD35, MSSRFPD36, MSSRFPH100, MSSRFPH124, MSSRFPH134, MSSRFPH139, and MSSRFPH145. The BOX-PCR fingerprinting analysis showed the existence of polymorphism by amplifying three distinct patterns among the isolates. Dendrogram generated based on BOX-PCR profile with Dice coefficient and the UPGMA clustering method with $90 \%$ tolerance level revealed the existence of three diverse cluster groups (Cluster I, II, and III) at $85 \%$ similarity coefficient (Supplementary Figure S2).

\section{Taxonomical Identification}

Two isolates from each BOX-PCR cluster groups were chosen and the 16S rRNA was amplified and sequenced for taxonomical identification. The EzTaxon analysis revealed that representative isolates of cluster groups I (MSSRFPD27 and MSSRFPD30), II (MSSRFPD28 and MSSRFPD36), and III (MSSRFPD29 and MSSRFPD35), showed $99.9 \%$ identity to $G$. nicotianae DSM $20123^{T}$, followed by $99.45 \%$ similarity index with G. mysorens LMG $16219^{T}$ and $99.24 \%$ with $G$. arilaitensis Re117 ${ }^{T}$. Phylogenetic analysis of 16S rRNA of the phenol degrading isolates and closest type strains sequence revealed the isolates from cluster groups I, II, and III formed a monophyletic clade with G. nicotianae DSM 20123 ${ }^{T}$ which indicates that MSSRFPD36 and other isolates belong to the group of G. nicotianae with high phenol degrading efficiency (Figure 1).

\section{Biodegradation of Phenol}

Based on the BOX-PCR and 16S rRNA analysis 3 polymorphic isolates MSSRFPD30, MSSRFPD35, and MSSRFPD36 were used to determine the phenol degrading efficiency and rate of degradation at $1000 \mathrm{mg} \mathrm{L}^{-1}$. Among the three strains, MSSRFPD35 rapidly degrade the $1000 \mathrm{mg} \mathrm{L}^{-1}$ of phenol completely within $48 \mathrm{~h}$ of incubation, followed by MSSRFPD30 and MSSRFPD36 in $60 \mathrm{~h}$ and $96 \mathrm{~h}$, respectively (Figure 2). This indicated strain MSSRFPD35 is highly potential and an efficient phenol degrading isolate obtained from this study.

\section{Growth Kinetics and Degradation Kinetics}

Time course assay of $G$. nicotianae MSSRFPD35 revealed that degradation of phenol at conc. range of 41.23 to $1117.11 \mathrm{mg}$ $\mathrm{L}^{-1}$ was reached within 6 and $60 \mathrm{~h}$, respectively, with maximum biomass of $1312 \mathrm{mg} \mathrm{L}^{-1}$ (Figure 3A). The biomass at different initial phenol concentration measured every $12 \mathrm{~h}$ at OD $600 \mathrm{~nm}$ was converted into dry biomass $\left(\mathrm{mg} \mathrm{L}^{-1}\right)$ to calculate growth rate (Figure 4). Haldane model showed a correlation coefficient $R^{2}$ value of 0.98 when inhibiting phenol concentrations were used as substrate and is well fitted with experimental data (Figure 3B). The predicted kinetic parameters were $\mu^{*} 0.574 \mathrm{~h}^{-1}, K_{\mathrm{s}} 20.29 \mathrm{mg}$ $\mathrm{L}^{-1}$ and $K_{\mathrm{i}} 268.1 \mathrm{mg} \mathrm{L}^{-1}$. The values of kinetic parameters $\mu^{*}$ predicted maximum growth rate, $K_{\mathrm{i}}$ inhibition constant and $K_{\mathrm{s}}$ half-saturation constant help in identification of substrate's inhibition character. True maximum growth rate $\left(\mu_{\max }\right)$ and substrate $\left(S_{\mathrm{m}}\right)$ concentration at which it occurred were calculated by Eqs. (7) and (6) as $0.37 \mathrm{~h}^{-1}$ and $73.76 \mathrm{mg} \mathrm{L}^{-1}$, respectively. Here graphically predicted growth rate $\mu^{*}(0.574)$ and true growth rate $\mu_{\max }(0.37)$ which were overestimated by $55 \%$ are shown in Table 1. Depletion of phenol concentration calculated for every $12 \mathrm{~h}$ up to $96 \mathrm{~h}$ was used to calculate the degradation rate of phenol (Figure 5). Degradation rate for each $S_{\text {i }}$ was calculated from the slope of the plot between negative logarithmic substrate concentration, $-\ln \left(S / S_{\mathrm{i}}\right)$ and time, $t$. The $q_{\mathrm{s}}$ values clearly showed an inhibition effect which was reduced when $S_{\mathrm{i}}$ was increased. The kinetic parameters were $q^{*} 1.244, K_{\mathrm{s}}{ }^{\prime} 9.152, K_{\mathrm{i}}{ }^{\prime} 517.5, S_{\mathrm{m}}{ }^{\prime}$ 68.820 and true maximum degradation rate $q^{\max } 0.983$ obtained (Table 2) with correlation coefficient value of 0.75 (Figure 3C).

\section{Molecular and Metabolic Pathways Involved in Phenol Degradation}

The genes coding for catechol 1,2-dioxygenase and catechol 2,3-dioxygenase that are involved in the degradation of phenol in MSSRFPD35 showed amplification of 409 bp and $816 \mathrm{bp}$, respectively. The BLASTX analysis of the amplified PCR product sequence showed similarity to catechol 1,2-dioxygenase with $98.25 \%$ identity to Glutamicibacter arilaitensis $\operatorname{Re} 117^{T}$ and Arthrobacter sp. W1, followed by $97.3 \%$, to Arthrobacter sp. MYb213 and Glutamicibacter sp. BW77 (Supplementary Figure S3). The sequence analysis of the amplified product of catechol 2,3-dioxygenase gene showed $96 \%$ identity with catechol 2,3-dioxygenase of $G$. mysorens, followed by $96.43 \%$ identity with 3,4-dihydroxyphenylacetate 2,3-dioxygenase of $G$. arilaitensis Re117 ${ }^{T}$ (Supplementary Figure S4). The enzymatic assay of MSSRFPD35 culture extract confirmed that it follows the ortho cleavage pathway by increasing absorbance at $260 \mathrm{~nm}$ from 0.035 to 0.079 by the formation of aromatic ring cleavage product cis, cis muconic acid. Enzyme activity of MSSRFPD35 toward catechol

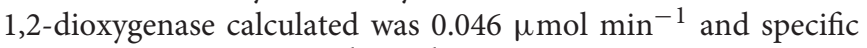
activity $0.008 \mu \mathrm{mol} \mathrm{min}{ }^{-1} \mu \mathrm{g}^{-1}$, whereas compounds denoting meta cleavage were not detected which was confirmed by no 


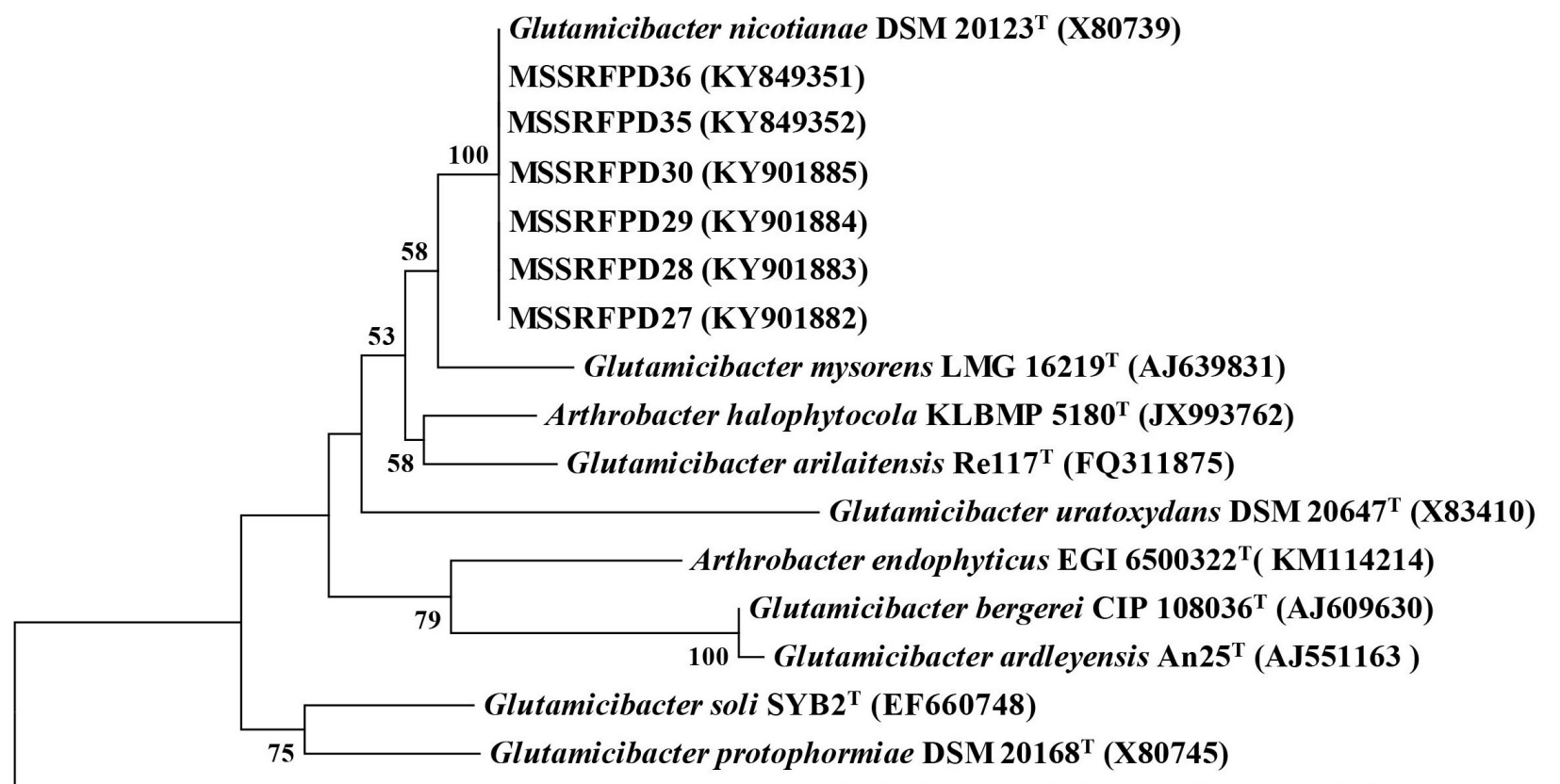

Arthrobacter halodurans JSM 078085 ${ }^{\mathrm{T}}$ (EU583729)

0.005

FIGURE 1 | Neighbor-joining tree based on partial 16S rRNA gene sequences of phenol degrading strains and other closely related strains.

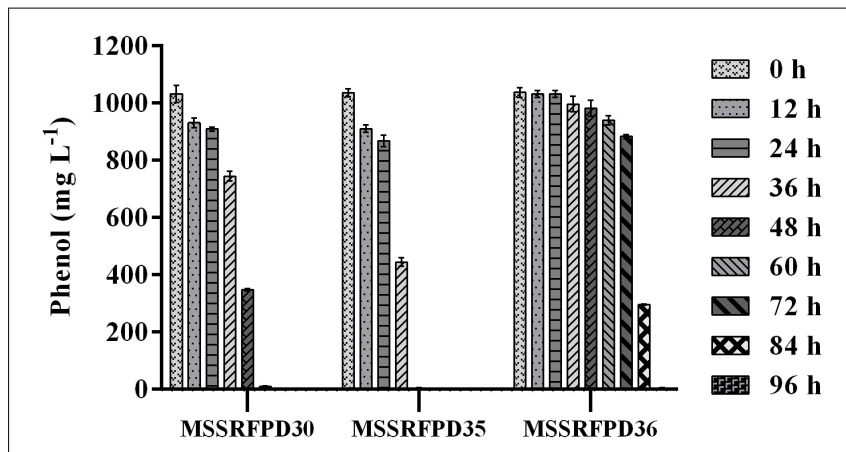

FIGURE 2 | Determination of phenol degradation efficiency of representative isolates from each BOX PCR cluster groups at $1000 \mathrm{mg} \mathrm{L}^{-1}$ phenol.

increase in absorbance at $375 \mathrm{~nm}$ and no specific enzyme activity was observed. It indicates that isolate MSSRFPD35 follows ortho cleavage pathway for the degradation of phenol though the genome information for meta pathway was also detected.

\section{Phenol Degrading Efficiency of MSSRFPD35 in the Presence of Different Heavy Metals}

The phenol degrading efficiency of MSSRFPD35 was not affected in the presence of heavy metal ions such as $\mathrm{Mn}\left(800 \mathrm{mg} \mathrm{L}^{-1}\right)$, $\mathrm{Zn}\left(600 \mathrm{mg} \mathrm{L}^{-1}\right), \mathrm{Pb}\left(200 \mathrm{mg} \mathrm{L}^{-1}\right)$, Ni $\left(20 \mathrm{mg} \mathrm{L}^{-1}\right)$. The phenol degradation was $99 \%$ in the presence of heavy metals $\mathrm{Pb}$ and $\mathrm{Ni}$, $83 \%$ and $93 \%$ in the presence of $\mathrm{Mn}$ and $\mathrm{Zn}$, respectively, with the time frame of $72 \mathrm{~h}$ (Figure 6). Heavy metal Cu $\left(20 \mathrm{mg} \mathrm{L}^{-1}\right)$ and Co (10 $\left.\mathrm{mg} \mathrm{L}^{-1}\right)$ amended medium had an inhibitory effect on phenol degradation, were in only $24 \%$ and $43 \%$ of phenol were degraded, respectively, in $72 \mathrm{~h}$ of incubation. While $\mathrm{Cd}$ (50 $\left.\mathrm{mg} \mathrm{L}^{-1}\right)$, Cr (50 $\left.\mathrm{mg} \mathrm{L}^{-1}\right)$, and $\mathrm{Hg}\left(200 \mathrm{mg} \mathrm{L}^{-1}\right)$ completely inhibited the growth of MSSRFPD35 and no phenol degradation was observed. The strain MSSRFPD35 grew in the presence of aromatic compounds like 4-nitrophenol (50 $\left.\mathrm{mg} \mathrm{L}^{-1}\right)$, gallic acid (200 $\left.\mathrm{mg} \mathrm{L}^{-1}\right)$, cinnamic acid $\left(100 \mathrm{mg} \mathrm{L}^{-1}\right)$, naphthol $(50 \mathrm{mg}$ $\left.\mathrm{L}^{-1}\right)$, tannic acid $\left(50 \mathrm{mg} \mathrm{L}^{-1}\right)$, naphthylamine $\left(50 \mathrm{mg} \mathrm{L}^{-1}\right)$, and catechol $\left(100 \mathrm{mg} \mathrm{L}^{-1}\right)$ by utilizing all of these as sole carbon source, but was not able to utilize 1-chloro-2,4-dinitrobenzene and failed to grow in the amended medium.

\section{Soil Microcosm}

The microcosm experiment conducted with soil slurry spiked with $65 \mathrm{mg} \mathrm{L}^{-1}, 110 \mathrm{mg} \mathrm{L}^{-1}$ and $240 \mathrm{mg} \mathrm{L}^{-1}$ of phenol showed $\sim 84 \%$ degradation when inoculated with MSSRFPD35 compared to uninoculated soil samples at 10 th day of incubation. In the soil slurry amended with $240 \mathrm{mg} \mathrm{L}^{-1}$ of phenol showed $94.9 \%$ degradation, followed by $84 \%$ of degradation of $65 \mathrm{mg} \mathrm{L}^{-1}$ and $91 \%$ of $110 \mathrm{mg} \mathrm{L}^{-1}$ degraded in 10 days of incubation (Figure 7). Control soils without bacterial inoculum showed no significant change in phenol concentration indicating no physiological degradation. Hence, MSSRFPD35 had the potential 

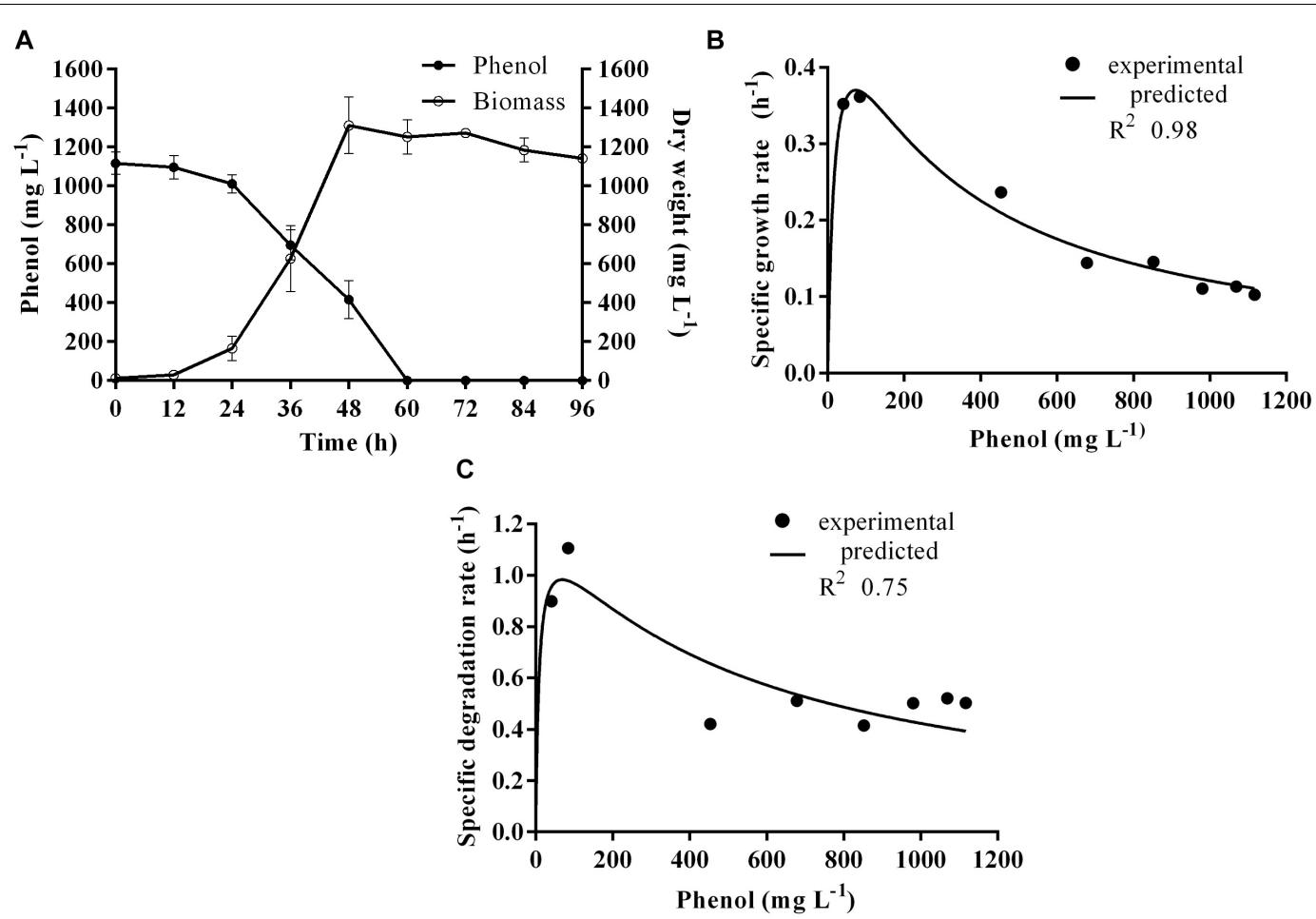

FIGURE 3 | (A) Time course of growth and phenol degradation by G. nicotianae MSSRFPD35 at initial phenol (B) relationship between specific growth rate ( $\mu$ ), and (C) specific degradation rate $(q)$ and initial substrate concentration $\left(S_{i}\right)$. Haldane's model simulation was fitted to the experimental values of $\mu$ and $q$.

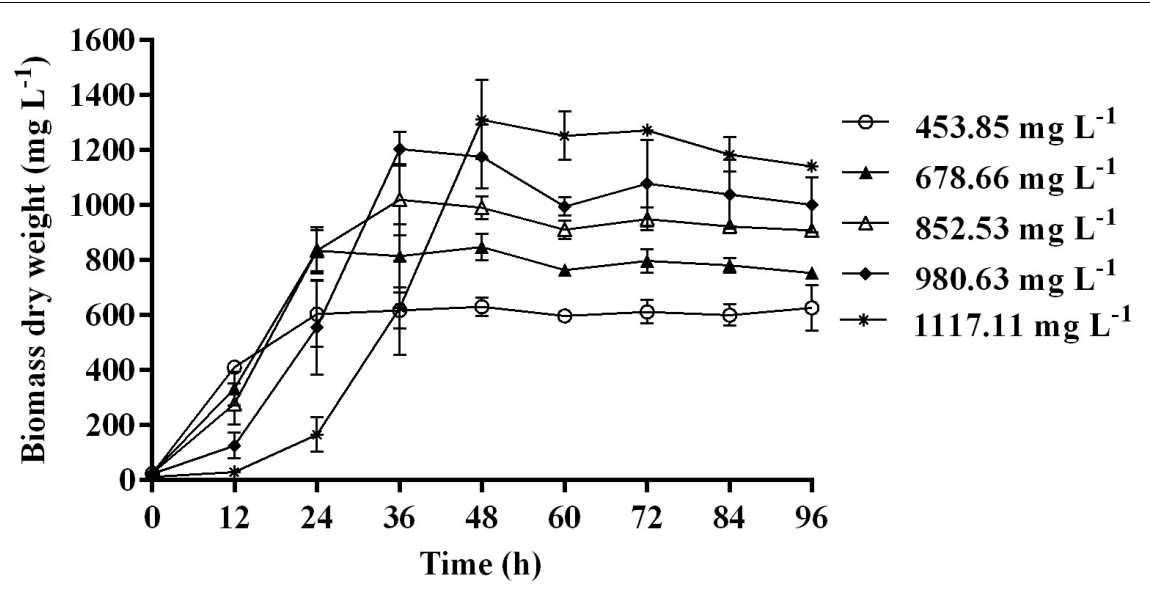

FIGURE 4 | Biomass of MSSRFPD35 at a various phenol substrate concentration.

to degrade phenol not only under laboratory conditions but also in contaminated soils.

\section{DISCUSSION}

Globally, contamination of phenol and its derivatives in soil and water from industrial effluents are increasing which have major toxic effects to all living organisms (Prasse et al., 2018; $\mathrm{Wu}$ et al., 2018). Bioremediation of toxic pollutants and inorganic components by microorganisms is a cost-effective and environmentally safe approach (Satchanska et al., 2015; Tiwari et al., 2017). Gu (2016) discussed the key components for efficient biodegradation of environmental pollutants, and hence understanding of the microbial system with the knowledge on metabolism, nutrient utilization, growth rate and subsequently kinetics are essential. This study for the first time attempted to isolate potential phenol degrading bacteria from distillery effluent contaminated $C$. indica rhizospheric soils. Among the microorganisms, bacterial species are often dominantly involved 
TABLE 1 | Growth kinetic fitting parameter of MSSRFPD35 and calculated parameters of different microbes grown in phenol.

\begin{tabular}{|c|c|c|c|c|c|c|c|}
\hline \multirow[t]{2}{*}{ Bacteria } & \multicolumn{6}{|c|}{ Parameters obtained for specific growth rate $(\mu)$} & \multirow[t]{2}{*}{ References } \\
\hline & $\mu_{\max }$ & $K_{\mathrm{s}}$ & $K_{\mathbf{i}}$ & $S_{m}$ & $\mu^{*} \max$ & $R^{2}$ & \\
\hline G. nicotianae MSSRFPD35 & 0.574 & 20.29 & 268.1 & 73.76 & 0.37 & 0.98 & This study \\
\hline P. putida LY1 & 0.217 & 24.40 & 121.70 & 54.50 & 0.114 & 0.96 & Li et al. (2010) \\
\hline P. putida MTCC 1194 & 0.109 & 53.20 & 148.60 & 88.90 & 0.050 & 0.91 & Mathur and Majumder (2010) \\
\hline Alcaligenes sp. TW1 & 0.58 & 10.00 & 550.00 & 74.20 & 0.457 & - & Essam et al. (2010) \\
\hline A. faecalis B6-2 & 0.48 & 469.23 & 188.16 & 297.10 & 0.12 & 0.90 & Heilbuth et al. (2015) \\
\hline A. johnsonii D1 & 0.55 & 483.83 & 2582.63 & 1117.80 & 0.29 & 0.96 & Heilbuth et al. (2015) \\
\hline B. brevis & 0.078 & 29.31 & 2434.70 & 267.10 & 0.064 & 0.95 & Arutchelvan et al. (2006) \\
\hline S. solfataricus $98 / 2$ & 0.094 & 77.70 & 319.40 & 157.50 & 0.047 & 0.95 & Christen et al. (2012) \\
\hline B. cereus MTCC 9817 & 0.4396 & 129.40 & 637.80 & 287.28 & 0.2312 & 0.81 & Banerjee and Ghoshal (2010a) \\
\hline Gulosibacter sp. YZ4 & 0.601 & 70.87 & 418.20 & - & - & 0.98 & Zhai et al. (2012) \\
\hline P. variotii JH6 & 0.312 & 130.40 & 200.00 & 161.493 & 0.11931 & 0.95 & Wang et al. (2010) \\
\hline C. tropicalis PHB5 & 0.3407 & 15.81 & 169.00 & 51.69 & 0.2113 & 0.99 & Basak et al. (2014) \\
\hline
\end{tabular}

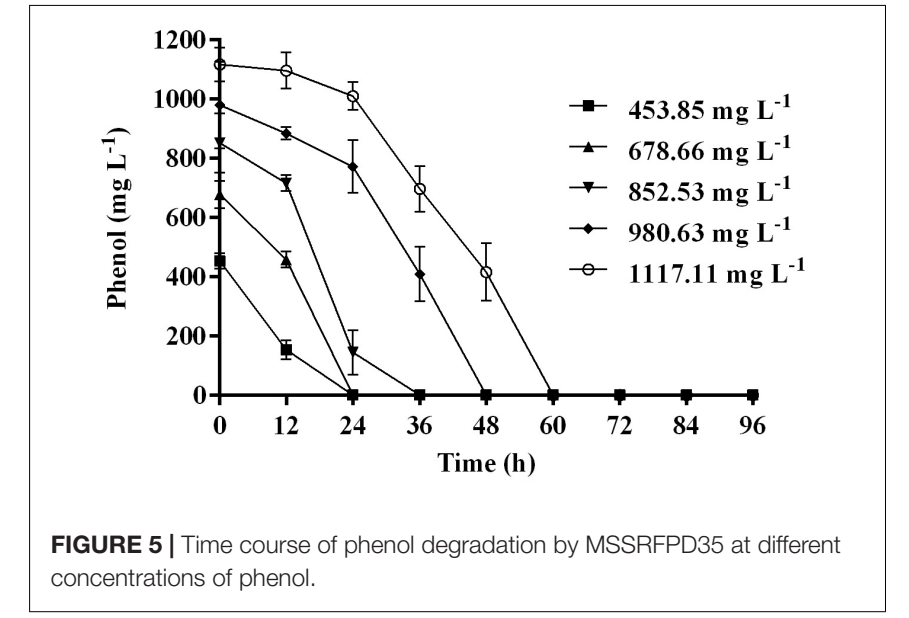

in the degradation of phenol and its derivatives (Whiteley et al., 2001; Banerjee and Ghoshal, 2010a; Pal et al., 2014; Shahryari et al., 2018; Wu et al., 2018). Our study also revealed the presence and abundance of diverse potential phenol degrading Arthrobacter strains associated with rhizosphere soils of $C$. indica. The $16 \mathrm{~S}$ rRNA analysis of all the cluster groups showed similarity to the strain $G$. nicotianae, reclassification of Arthrobacter nicotianae (Busse, 2016) but the BOX-DNA fingerprinting analysis significantly showed the existence of an intra-species population. Ellegaard and Engel (2016) reported that intra-species variation cannot be resolved using 16S rRNA based analysis because of high sequence conservation in the $16 \mathrm{~S}$ rRNA gene. The strains showed different degrees of phenol degradation indicating the intra-species genetic variation in the BOX PCR fingerprinting pattern. The genetic variation among the clustered identical isolates might exhibit significant variation in the phenol degradation efficiency. This indicates that the genotypic and phenotypic plasticity of the strains is due to the lateral gene transfer which was observed in several other genera associated in different niches (Whiteley et al., 2001; Bedhomme et al., 2019).

Among the bacterial genera, Arthrobacter sp. class 1 microorganism are reported as key candidates involved in the degradation of phenolic compounds habited in soil and rhizosphere regions (Arora and Sharma, 2015; TRBA, 2015; Wang et al., 2015; Busse, 2016). Studies using Arthrobacter nicotianae sp. W1 which preferentially grew on ethylbenzene, toluene, catechol, benzene, xylene, and cresol involved a synergistic mechanism in the degradation process (Ma et al., 2013; Wong et al., 2015) of pentachloronitrobenzene (Wang et al., 2015). In this study, we are reporting G. nicotianae MSSRFPD35

TABLE 2 | Degradation kinetic fitting parameter and calculated parameters of different microbes grown in phenol.

\begin{tabular}{|c|c|c|c|c|c|c|c|}
\hline \multirow[t]{2}{*}{ Microorganisms } & \multicolumn{6}{|c|}{ Parameters obtained for specific degradation rate $(q)$} & \multirow[t]{2}{*}{ References } \\
\hline & $q^{*}$ & $K_{\mathbf{s}^{\prime}}$ & $\boldsymbol{K}_{\mathrm{i}}^{\prime}$ & $S_{m^{\prime}}$ & $q_{\max }$ & $R^{2}$ & \\
\hline G. nicotianae MSSRFPD35 & 1.244 & 9.152 & 517.5 & 68.820 & 0.983 & 0.7542 & This study \\
\hline B. cereus MTCC 9817 & 27.85 & 59,150 & 2.411 & 377.63 & 0.089 & 0.64 & Banerjee and Ghoshal (2010b) \\
\hline B. cereus MTCC 9818 & 1.635 & 9.706 & 3873.00 & 193.88 & 1.486 & 0.82 & Banerjee and Ghoshal (2010b) \\
\hline Stenotrophomonas maltophilia CUPS-3 & 58.80 & 1688.00 & 0.868 & 38.27 & 0.659 & 0.84 & Pal et al. (2014) \\
\hline Pseudomonas sp. CUPS-2 & 34.39 & 850.50 & 0.878 & 27.32 & 0.544 & 0.98 & Pal et al. (2014) \\
\hline P. aeruginosa CUPS-5 & 14.31 & 252.60 & 2.468 & 24.96 & 0.674 & 0.94 & Pal et al. (2014) \\
\hline S. solfataricus $98 / 2$ & - & 130.30 & 291.10 & 174.9 & 0.110 & 0.93 & Christen et al. (2012) \\
\hline C. tropicalis PHB5 & 0.2766 & 2.819 & 2093.00 & 76.81 & 0.257 & 0.82 & Basak et al. (2014) \\
\hline
\end{tabular}




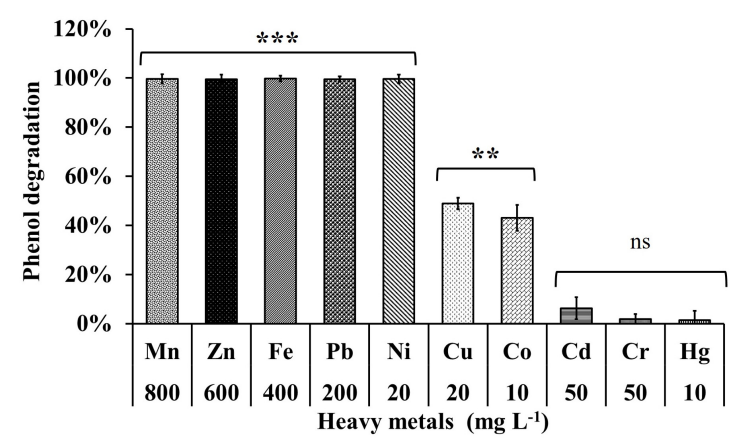

FIGURE 6 | Phenol degradation profiles of MSSRFPD35 under the influence of different heavy metals. Values are mean $\pm \mathrm{SD}$ of triplicate sets,

${ }^{\star \star} P$-value $=0.01-0.001,{ }^{\star \star \star} P$-value $=$ less than 0.001 and ${ }^{n s} P$-value greater than 0.05 represent the significant difference according to Duncan multiple range test compared to control.

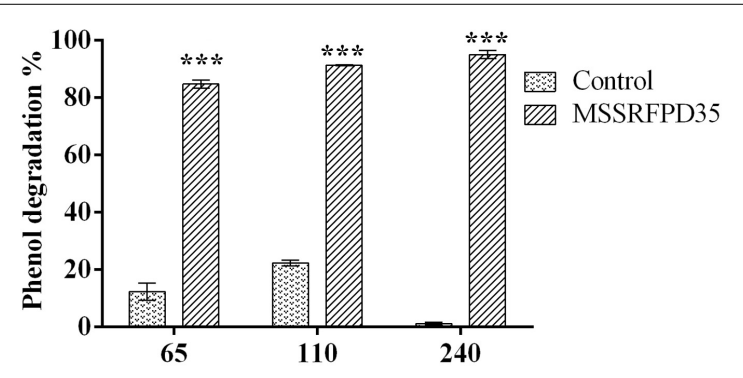

Phenol (mg L $\left.{ }^{-1}\right)$

FIGURE 7 | Degradation level of phenol by MSSRFPD35 in sterile soil microcosm. Values are mean $\pm \mathrm{SD}$ of triplicate sets, ${ }^{* * *} P$-value $=$ less than 0.001 represent the significant difference according to Duncan multiple range test compared to control.

with potential to degrade phenol up to $1113 \mathrm{mg} \mathrm{L}^{-1}$ within $60 \mathrm{~h}$ under minimal nutrient conditions, comparatively this is one of the efficient phenol degrading strain reported so far. Among the G. nicotianae isolates from this study, the degree of phenol degradation varied significantly, which indicates that degradation potential is not strongly associated with the genus (or) species. The potential of phenol degradation is a specific trait of the individual strain. Several studies reported that degree of phenol degradation and other functional traits varies among the same group, due to its habitat, presence of respective gene and its level of expression (Wang et al., 2015; Tian et al., 2017; Bedhomme et al., 2019). Strain Arthrobacter citreus was reported to degrade $470 \mathrm{mg} \mathrm{L}^{-1}$ phenol in $24 \mathrm{~h}$ (Karigar et al., 2006); Arthrobacter chlorophenolicus A6 has potential to degrade high concentrations of 4-CP (up to $347 \mathrm{mg} \mathrm{L}^{-1}$ ), 4-nitrophenol and 4-bromophenol phenol derivatives (Westerberg et al., 2000). Phenol degradation by Acinetobacter sp. SA01 isolated from farmland contaminated with pesticides and oil refinery pollutants was observed at $1000 \mathrm{mg} \mathrm{L}^{-1}$ of phenol after $60 \mathrm{~h}$ under the optimum condition of $\mathrm{pH} 7,30^{\circ} \mathrm{C}$ and $180 \mathrm{rpm}$ (Shahryari et al., 2018). P. putida MTCC 1194 degrade phenol at concentration of $1000 \mathrm{mg} \mathrm{L}^{-1}$ in $162 \mathrm{~h}$ (Kumar et al., 2005). Strain Kocuria sp. TIBETAN4 isolated from hyper-saline and alkaline soda lake soil could degrade $470.5 \mathrm{mg} \mathrm{L}^{-1}$ phenol within 3 days, $705 \mathrm{mg}$ $\mathrm{L}^{-1}$ phenol within 4 days, but the degradation of $941 \mathrm{mg} \mathrm{L}^{-1}$ phenol was lengthened to 10 days for complete degradation (Wu et al., 2018).

In the time course assay lag phase of $G$. nicotianae MSSRFPD35 extended with increasing phenol concentration in the medium, which prolonged the time of biodegradation. Shahryari et al. (2018) reported $18 \mathrm{~h}$ lag phase stage of Acinetobacter sp. SA01 and Pseudomonas sp. NCCP-407 to degrade $1000 \mathrm{mg} \mathrm{L}^{-1}$ and $750 \mathrm{mg} \mathrm{L}^{-1}$ of phenol, respectively. Christen et al. (2012) stated that the bacterial cultures that were acclimatized in appropriate substrate concentration had less or no lag phase. However, MSSRFPD35 had no lag phase up to $980 \mathrm{mg} \mathrm{L}^{-1}$ of phenol, but increasing concentration up to $1117 \mathrm{mg} \mathrm{L}^{-1}$ of phenol had $12 \mathrm{~h}$ of lag phase which depict the efficiency of MSSRFPD35 to acclimatize to high phenol concentrations. Increasing concentration of phenol can influence changes in the cell membrane and protect the cell from toxic effects of phenol (Murinova and Dercova, 2014) also the cell takes a longer time to adapt to phenol toxicity. The specific growth rate of MSSRFPD35 strain was higher than P. putida LY1 (Li et al., 2010), Bacillus brevis (Arutchelvan et al., 2006) and Sulfolobus solfataricus 98/2 (Christen et al., 2012). It was almost equivalent to earlier reported potential phenol degrading strains like Alcaligenes sp. TW1 (Essam et al., 2010) and B. cereus MTCC 9817 (Banerjee and Ghoshal, 2010b). Gulosibacter sp. YZ4 has a higher specific growth rate of $0.6 \mathrm{mg} \mathrm{L}^{-1}$ which can degrade $2000 \mathrm{mg} \mathrm{L}^{-1}$ of phenol within $72 \mathrm{~h}$ (Zhai et al., 2012). Similarly, MSSRFPD35 can degrade $1100 \mathrm{mg} \mathrm{L}^{-1}$ of phenol within $60 \mathrm{~h}$.

The $K_{\mathrm{s}}$ values which depict the affinity toward the phenol substrate was on the lower side for MSSRFPD35 and is equivalent to P. putida LY1, Candida tropicalis PHB5 and Bacillus brevis. Inhibition constant $K_{\mathrm{i}}$ for $G$. nicotianae MSSRFPD35 was in medium-range among reported strains and it is similar to Paecilomyces variotii JH6 (Wang et al., 2010) and S. solfataricus 98/2 (Christen et al., 2012). The $K_{\mathrm{i}}$ value in this study indicates the higher tolerance of MSSRFPD35 toward phenol when compared to other bacteria reported. Higher values of $K_{\mathrm{i}}$ denote lower inhibition which leads to Monod kinetic model and also indicates the concentration up to which the bacterial strain can tolerate shock loads (Bajaj et al., 2009). Inconsistency among the predicted $\left(\mu^{*}\right)$ and true $\left(\mu_{\max }\right)$ maximum growth rate were demonstrated in earlier studies conducted using substrate phenol (Christen et al., 2012; Basak et al., 2014). In this study, graphically predicted $\mu^{*}(0.574)$ and true growth rate $\mu_{\max }(0.37)$ were overestimated. However, compared to other bacteria the $\mu_{\max }$ of MSSRFPD35 was second higher after Alcaligenes sp. TW1 (Essam et al., 2010). Though $S_{\mathrm{m}}$ of MSSRFPD35 was lower among few previous studies, it was higher than C. tropicalis PHB5 and P. putida LY1 but equal to Alcaligenes sp. TW1. This indicates that phenol concentration of $73.76 \mathrm{mg} \mathrm{L}^{-1}$ is the optimal substrate concentration for bacterial growth, while increment in substrate concentration above this inhibited the bacterial growth and biomass formation. Higher values of specific growth rate denoted that MSSRFPD35 can utilize the phenol in a comparatively lesser 
duration of $60 \mathrm{~h}$. Though specific degradation rate is usually independent of $S_{\mathrm{i}}$, phenol as a substrate showed inhibitory effect on specific degradation rate $q_{\mathrm{s}}$ in different studies (Yan et al., 2005; Bai et al., 2007).

Molecular analysis showed the MSSRFPD35 catechol 1,2-dioxygenase gene sequence confirms the similarity to Glutamicibacter spp., while catechol 2,3-dioxygenase enzymecoding gene sequence showed similarity only with catechol 2,3-dioxygenase of G. mysorens. The sequence results did match with 3,4-dihydroxyphenylacetate and 2,3-dioxygenase gene of Glutamicibacter sp. Even though primers were designed to target a highly specific region of catechol 2,3-dioxygenase enzyme-coding gene, it was not depicted in blast analysis. Its due to the diversity in the enzyme gene sequence regions which is highly variable with less similarity to the target enzyme sequence, whereas both enzymes, homoprotocatechuate 2,3-dioxygenase and catechol 2,3-dioxygenase belongs to the same family of oxidoreductases and is involved in decyclizing of aromatic ring (Sandhu et al., 2009; Tian et al., 2017). The results confirmed that MSSRFPD35 and other Glutamicibacter sp. in this study might possess coding regions for both catechol 1,2-dioxygenase and catechol 2,3-dioxygenase enzymes. Though the gene coding for catechol 2,3-dioxygenase was amplified from the genomic DNA of MSSRFPD35, only catechol 1,2-dioxygenase enzymatic activity was detected indicating that MSSRFPD35 adopted ortho pathway to breakdown catechol intermediate and not meta pathway. Similarly in S. solfataricus 98/2 phenol degradation adopted the meta pathway with catechol 2,3-dioxygenase enzyme, though it possesses both catechol 1,2-dioxygenase and catechol 2,3-dioxygenase genes (Comte et al., 2013). Alkylphenol degrading Pseudomonas sp. TX1, and P. putida TX2 were reported to possess coding genes for both the enzymes (Tuan et al., 2011).

Glutamicibacter spp. were reported to degrade aromatic derivatives like pentachlorobenzene, $p$-cresol, benzene and toluene, even though the toxicity of aromatic compounds depends on other functional groups attached to the derivatives, most of them formed intermediate in the form of catechol derivatives (Vikram et al., 2013). Wang et al. (2009) reported G. nicotianae W1 adopted ortho pathway in the degradation of phenol $p$-cresol and mixed phenolic compounds. Presence of catechol dioxygenase enzyme in MSSRFPD35 evidenced that the catechol derivatives could be cleaved and can be converted to simpler forms. For example, distillery effluent contains phenolic acids and its derivatives like gallic acid, cinnamic acids and also other aromatic derivatives that are abundantly used in pesticide, plastic, explosives petrochemical and organic synthesis industries (Arora and Jain, 2012).

The strain MSSRFPD35 could degrade high levels of synthetic phenol in the presence of different heavy metals; present in industrial effluents that are predominantly contaminated with phenolic and other aromatic derivatives. It is an added functional property of the strain and the application may be expanded in the bioremediation of effluents discharged from the industries. Phenol degrading efficiency in the presence of heavy metals is an important criteria for a strain as these heavy metals are released as co-contaminates along with phenol that would inhibit the bacterial growth and decrease the biodegradation efficiency (Thavamani et al., 2012; Wong et al., 2015). Majority of the heavy metals are reported to be toxic to many bacterial groups by altering the cell morphology, disrupting the cell membrane, directly inhibiting the electron transport enzyme activity, decreasing the biomass, inhibiting growth and damaging the nucleic acid structure (Nies, 1999; Bruins et al., 2000; Sandrin and Maier, 2003; Janicka-Russak et al., 2008). But certain bacterial groups exhibit tolerance to multiple heavy metals at varied concentrations. The major mechanism involved in tolerance is through intracellular and extracellular metal sequestration, metal oxidation, methylation, demethylation, metal-organic complexion, metal-ligand degradation, exclusion by permeability barrier, and production of metal chelators like metallothioneins and exopolysaccharide (Ramasamy and Banu, 2007; Igiri et al., 2018). Silva et al. (2012) reported that the presence of heavy metals $\mathrm{Fe}^{3+}$ and $\mathrm{Mn}^{2+}$ stimulated the catechol dioxygenase activity of Gordonia polyisoprenivorans. Copper metal has a negative reaction toward Fe-S enzymes like ringhydroxylating dioxygenases and intradiol cleavage dioxygenase which are involved in aromatic metabolic pathway (Grass et al., 2011). Yeom and Yoo (1997) reported that benzene and toluene degradation by Alcaligenes xylosoxidans Y234 were highly inhibited by $\mathrm{Co}^{2+}$ and $\mathrm{Ag}^{+}$and $\mathrm{Cu}^{2+}$ which affects the catechol 1,2 dioxygenase enzymatic reaction. Lima et al. (2008) reported that Burkholderia cepacia utilized phenol $\left(100 \mu \mathrm{g} \mathrm{ml}^{-1}\right)$ in the presence of $\mathrm{K}_{2} \mathrm{Cr}_{2} \mathrm{O}_{7}$ at the concentration of 100 to $200 \mu \mathrm{g} \mathrm{ml}^{-1}$. Similarly, El-Naas et al. (2009) reported biodegradation of phenol by $P$. putida at the concentration of $150 \mathrm{mg} \mathrm{L}^{-1}$ and reported heavy metal ions such as iron, aluminum and zinc had no effect on the phenol biodegradation rate. Ontanon et al. (2015) reported degradation of phenol by Bacillus at maximum concentrations of $1000 \mathrm{mg} \mathrm{L}^{-1}$ and reduced $\mathrm{Cr}$ (VI) to $\mathrm{Cr}$ (III). This study revealed the potential of MSSRFPD35 in degrading phenol in the presence of different heavy metals. Satchanska et al. (2015) also reported that bacterial strains $B$. subtilis KCMRG5 and $P$. rhodesiae KCMR5 were able to degrade phenol in the presence of heavy metals. P. fluorescens (BBN1) and P. corrugata (BBB2) were reported to degrade $\mathrm{PAH}$ which were able to tolerate $993.6 \mathrm{mg}$ $\mathrm{L}^{-1}-\mathrm{Pb}\left(\mathrm{NO}_{3}\right)_{2}, 717.83 \mathrm{mg} \mathrm{L}{ }^{-1}-\mathrm{ZnSO}_{4}$ and $499.36 \mathrm{mg} \mathrm{L}^{-1}$ $\mathrm{CuSO}_{4}$, respectively (Máthé et al., 2012). However, no evaluation of heavy metal effect on phenol biodegradation by $G$. nicotianae has previously been performed. The present study indicates that G. nicotianae MSSRFPD35 strain can degrade phenol in the presence of $\mathrm{Pb}, \mathrm{Ni}, \mathrm{Cu}, \mathrm{Co}, \mathrm{Mn}$, and $\mathrm{Zn}$ metals which might occur as co-pollutants in industrial effluent. Soil microcosm studies also confirmed the in vivo bioremediation potential of MSSRFPD35 and to degrade phenol in contaminated soils. Though there are no studies on soil microcosm with phenol as a substrate, some studies reported $90 \%$ degradation of chloro-nitro phenol by Burkholderia sp. RKJ 800 (Arora and Jain, 2012) and Cupriavidus sp. a3 (Tiwari et al., 2017) and 2 nitrobenzene by Arthrobacter sp. SPG in soil (Arora and Sharma, 2015). Strain MSSRFPD35 holding a capacity of tolerating heavy metals, degrading relatively high concentrations of phenol in a shorter time and other phenol derivatives showed promising prospect for application in the remediation of phenol contaminated sites. 


\section{CONCLUSION}

The strain G. nicotianae MSSRFPD35 proved to degrade phenol at relatively high concentration via catechol 1,2-dioxygenase directed ortho pathway, specifically in the presence of different heavy metals. The growth and degradation kinetics of the strain MSSRFPD35 utilizing phenol as a sole carbon and nutrient source was well characterized by Haldane model where the $\mu_{\max }, K_{\mathrm{i}}$ and $K_{\mathrm{s}}$ were described. The strain was capable of growing in various monocyclic and polycyclic aromatic hydrocarbons, tolerate and degrade phenol in the presence of heavy metals like lead, zinc, manganese, iron, and nickel. The versatility of this strain can be exploited for promoting it as a renewable resource for biodegradation of phenol and its derivatives co-contaminated with heavy metals discharged from various industries.

\section{DATA AVAILABILITY STATEMENT}

The datasets presented in this study can be found in online repositories. The names of the repository/repositories and accession number(s) can be found in the article/Supplementary Material.

\section{REFERENCES}

APHA (2017). Standard Methods for the Examination of Water and Wastewater. Washington, DC: American Public Health Association.

Arora, P. K., and Jain, R. K. (2012). Metabolism of 2-chloro-4-nitrophenol in a Gram negative bacterium, Burkholderia sp. RKJ 800. PLoS One 7:e38676. doi: 10.1371 /journal.pone.0038676

Arora, P. K., and Sharma, A. (2015). New metabolic pathway for degradation of 2-nitrobenzoate by Arthrobacter sp. SPG. Front. Microbiol. 6:551. doi: 10.3389/ fmicb.2015.00551

Arutchelvan, V., Kanakasabai, V., Elangovan, R., Nagarajan, S., and Muralikrishnan, V. (2006). Kinetics of high strength phenol degradation using Bacillus brevis. J. Hazard. Mater. 129, 216-222. doi: 10.1016/j.jhazmat. 2005.08.040

Bai, J., Wen, J.-P., Li, H.-M., and Jiang, Y. (2007). Kinetic modeling of growth and biodegradation of phenol and $\mathrm{m}$-cresol using Alcaligenes faecalis. Process. Biochem. 42, 510-517. doi: 10.1016/j.procbio.2006.10.004

Bajaj, M., Gallert, C., and Winter, J. (2009). Phenol degradation kinetics of an aerobic mixed culture. Biochem. Eng. J. 46, 205-209. doi: 10.1016/j.bej.2009.05. 021

Banerjee, A., and Ghoshal, A. K. (2010a). Isolation and characterization of hyper phenol tolerant Bacillus sp. from oil refinery and exploration sites. J. Hazard. Mater. 176, 85-91. doi: 10.1016/j.jhazmat.2009.11.002

Banerjee, A., and Ghoshal, A. K. (2010b). Phenol degradation by Bacillus cereus: pathway and kinetic modeling. Bioresour. Technol. 101, 5501-5507. doi: 10. 1016/j.biortech.2010.02.018

Basak, B., Bhunia, B., Dutta, S., Chakraborty, S., and Dey, A. (2014). Kinetics of phenol biodegradation at high concentration by a metabolically versatile isolated yeast Candida tropicalis PHB5. Environ. Sci. Pollut. Res. Int. 21, 14441454. doi: 10.1007/s11356-013-2040-z

Bedhomme, S., Amoros-Moya, D., Valero, L. M., Bonifaci, N., Pujana, M. A., and Bravo, I. G. (2019). Evolutionary changes after translational challenges imposed by horizontal gene transfer. Genome Biol. Evol. 11, 814-831. doi: 10.1093/gbe/ evz031

Bhardwaj, P., Sharma, A., Sagarkar, S., and Kapley, A. (2015). Mapping atrazine and phenol degradation genes in Pseudomonas sp.

\section{AUTHOR CONTRIBUTIONS}

PD collected the samples, designed and performed the experiments, data analysis and drafted the manuscript. JS and AA supported sample collection, contributed to in vitro experiments, molecular analysis and manuscript correction. PR supervised and supported the study, revised the manuscript and approved for publishing. All authors contributed to the article and approved the submitted version.

\section{ACKNOWLEDGMENTS}

We thank Prof. M. S. Swaminathan, Founder Chairman, and Executive Director, M. S. Swaminathan Research Foundation, for their support and encouragement. We acknowledge the financial support from the Department of Biotechnology, Ministry of Science and Technology, Government of India, New Delhi, India.

\section{SUPPLEMENTARY MATERIAL}

The Supplementary Material for this article can be found online at: https://www.frontiersin.org/articles/10.3389/fmicb. 2020.01573/full\#supplementary-material

EGD-AKN5. Biochem. Eng. J. 102, 125-134. doi: 10.1016/j.bej.2015. 02.029

Bruins, M. R., Kapil, S., and Oehme, F. W. (2000). Microbial resistance to metals in the environment. Ecotoxicol. Environ. Saf. 45, 198-207. doi: 10.1006/eesa.1999. 1860

Busse, H. J. (2016). Review of the taxonomy of the genus Arthrobacter, emendation of the genus Arthrobacter sensu lato, proposal to reclassify selected species of the genus Arthrobacter in the novel genera Glutamicibacter gen. nov., Paeniglutamicibacter gen. nov., Pseudoglutamicibacter gen. nov., Paenarthrobacter gen. nov. and Pseudarthrobacter gen. nov., and emended description of Arthrobacter roseus. Int. J. Syst. Evol. Microbiol. 66, 9-37. doi: 10.1099/ijsem.0.000702

Cao, B., Geng, A., and Loh, K. C. (2008). Induction of ortho- and meta-cleavage pathways in Pseudomonas in biodegradation of high benzoate concentration: MS identification of catabolic enzymes. Appl. Microbiol. Biotechnol. 81, 99-107. doi: 10.1007/s00253-008-1728-3

Chen, J., Zhang, L., Jin, Q., Su, C., Zhao, L., Liu, X., et al. (2017). Bioremediation of phenol in soil through using a mobile plant-endophyte system. Chemosphere 182, 194-202. doi: 10.1016/j.chemosphere.2017.05.017

Christen, P., Vega, A., Casalot, L., Simon, G., and Auria, R. (2012). Kinetics of aerobic phenol biodegradation by the acidophilic and hyperthermophilic archaeon Sulfolobus solfataricus 98/2. Biochem. Eng. J. 62, 56-61. doi: 10.1016/j. bej.2011.12.012

Comte, A., Christen, P., Davidson, S., Pophillat, M., Lorquin, J., Auria, R., et al. (2013). Biochemical, transcriptional and translational evidences of the phenolmeta-degradation pathway by the hyperthermophilic Sulfolobus solfataricus 98/2. PLoS One 8:e82397. doi: 10.1371/journal.pone.0082397

Ellegaard, K. M., and Engel, P. (2016). Beyond 16S rRNA community profiling: intra-species diversity in the gut microbiota. Front. Microbiol. 7:1475. doi: 10. 3389/fmicb.2016.01475

El-Naas, M. H., Al-Muhtaseb, S. A., and Makhlouf, S. (2009). Biodegradation of phenol by Pseudomonas putida immobilized in polyvinyl alcohol (PVA) gel. J. Hazard. Mater. 164, 720-725. doi: 10.1016/j.jhazmat.2008. 08.059

Essam, T., Amin, M. A., El Tayeb, O., Mattiasson, B., and Guieysse, B. (2010). Kinetics and metabolic versatility of highly tolerant phenol degrading 
Alcaligenes strain TW1. J. Hazard. Mater. 173, 783-788. doi: 10.1016/j.jhazmat. 2009.09.006

Fan, Y., Zhu, T., Li, M., He, J., and Huang, R. (2017). Heavy metal contamination in soil and brown rice and human health risk assessment near three mining areas in central China. J. Healthc. Eng. 2017:4124302. doi: 10.1155/2017/4124302

Feist, C. F., and Hegeman, G. D. (1969). Phenol and benzoate metabolism by Pseudomonas putida: regulation of tangential pathways. J. Bacteriol. 100, 869877. doi: 10.1128/jb.100.2.869-877.1969

Grass, G., Rensing, L., and Rensing, C. (2011). Metal toxicity. Metallomics 3, 1095-1097. doi: 10.1039/c1mt90048j

Gu, J.-D. (2016). Biodegradation testing: so many tests but very little new innovation. Appl. Environ. Biotechnol. 1, 92-95.

Haddadi, A., and Shavandi, M. (2013). Biodegradation of phenol in hypersaline conditions by Halomonas sp. strain PH2-2 isolated from saline soil. Int. Biodeterior. Biodegradation. 85, 29-34. doi: 10.1016/j.ibiod.2013. 06.005

Hamzah, R. Y., and Al-Baharna, B. S. (1994). Catechol ring-cleavage in Pseudomonas cepacia: the simultaneous induction of ortho and meta pathways. Appl. Microbiol. Biotechnol. 41, 250-256. doi: 10.1007/bf00186968

Hasan, S. A., and Jabeen, S. (2015). Degradation kinetics and pathway of phenol by Pseudomonas and Bacillus species. Biotechnol. Biotechnol. Equip. 29, 45-53. doi: $10.1080 / 13102818.2014 .991638$

Heilbuth, N. M., Linardi, V. R., Monteiro, A. S., da Rocha, R. A., Mimim, L. A., and Santos, V. L. (2015). Estimation of kinetic parameters of phenol degradation by bacteria isolated from activated sludge using a genetic algorithm. J. Chem. Technol. Biotechnol. 90, 2066-2075. doi: 10.1002/jctb.4518

Heras, J., Dominguez, C., Mata, E., Pascual, V., Lozano, C., Torres, C., et al. (2015). GelJ-a tool for analyzing DNA fingerprint gel images. BMC Bioinformatics 16:270. doi: 10.1186/s12859-015-0703-0

Hussain, A., Dubey, S. K., and Kumar, V. (2015). Kinetic study for aerobic treatment of phenolic wastewater. Water Resour. Ind. 11, 81-90. doi: 10.1016/j. wri.2015.05.002

Igiri, B. E., Okoduwa, S. I. R., Idoko, G. O., Akabuogu, E. P., Adeyi, A. O., and Ejiogu, I. K. (2018). Toxicity and bioremediation of heavy metals contaminated ecosystem from tannery wastewater: a review. J. Toxicol. 2018:2568038. doi: $10.1155 / 2018 / 2568038$

Iqbal, A., Arshad, M., Hashmi, I., Karthikeyan, R., Gentry, T. J., and Schwab, A. P. (2018). Biodegradation of phenol and benzene by endophytic bacterial strains isolated from refinery wastewater-fed Cannabis sativa. Environ. Technol. 39, 1705-1714. doi: 10.1080/09593330.2017.1337232

Janicka-Russak, M., Kabała, K., Burzyński, M., and Kłobus, G. (2008). Response of plasma membrane $\mathrm{H}+$-ATPase to heavy metal stress in Cucumis sativu s roots. J. Exp. Bot. 59, 3721-3728. doi: 10.1093/jxb/ern219

Jiang, L., Ruan, Q., Li, R., and Li, T. (2013). Biodegradation of phenol by using free and immobilized cells of Acinetobacter sp. BS8Y. J. Basic Microbiol. 53, 224-230. doi: $10.1002 /$ jobm. 201100460

Jusoh, N., and Razali, F. (2008). Microbial consortia from residential wastewater for bioremediation of phenol in a chemostat. J. Teknol. 48, 51-60. doi: 10.11113/jt. $\mathrm{v} 48.233$

Karigar, C., Mahesh, A., Nagenahalli, M., and Yun, D. J. (2006). Phenol degradation by immobilized cells of Arthrobacter citreus. Biodegradation 17, 47-55. doi: 10.1007/s10532-005-3048-y

Kim, O. S., Cho, Y. J., Lee, K., Yoon, S. H., Kim, M., Na, H., et al. (2012). Introducing EzTaxon-e: a prokaryotic 16S rRNA gene sequence database with phylotypes that represent uncultured species. Int. J. Syst. Evol. Microbiol. $62(\mathrm{Pt}$ 3), 716-721. doi: 10.1099/ijs.0.038075-0

Kumar, A., Kumar, S., and Kumar, S. (2005). Biodegradation kinetics of phenol and catechol using Pseudomonas putida MTCC 1194. Biochem. Eng. J. 22, 151-159. doi: 10.1016/j.bej.2004.09.006

Kumar, S., Stecher, G., and Tamura, K. (2016). MEGA7: molecular evolutionary genetics analysis version 7.0 for Bigger Datasets. Mol. Biol. Evol. 33, 1870-1874. doi: 10.1093/molbev/msw054

Li, Y., Li, J., Wang, C., and Wang, P. (2010). Growth kinetics and phenol biodegradation of psychrotrophic Pseudomonas putida LY1. Bioresour. Technol. 101, 6740-6744. doi: 10.1016/j.biortech.2010.03.083

Lima, A., Pereira, M., Geraldo, R., Silva Filho, R., and Hofer, E. (2008). Utilization of phenol in the presence of heavy metals by metal-tolerant nonfermentative gram-negative ba-cteria isolated from wastewater. Rev. Latinoam. Microbiol. 49, 68-73.

Ma, F., Shi, S. N., Sun, T. H., Li, A., Zhou, J. T., and Qu, Y. Y. (2013). Biotransformation of benzene and toluene to catechols by phenol hydroxylase from Arthrobacter sp. W1. Appl. Microbiol. Biotechnol. 97, 5097-5103. doi: 10.1007/s00253-012-4301-z

Mahiudddin, M., Fakhruddin, A. N., Abdullah, and Al, M. (2012). Degradation of phenol via meta cleavage pathway by Pseudomonas fluorescens PU1. ISRN Microbiol. 2012:741820. doi: 10.5402/2012/741820

Máthé, I., Benedek, T., Táncsics, A., Palatinszky, M., Lányi, S., and Márialigeti, K. (2012). Diversity, activity, antibiotic and heavy metal resistance of bacteria from petroleum hydrocarbon contaminated soils located in Harghita County (Romania). Int. Biodeterior. Biodegradation 73, 41-49. doi: 10.1016/j.ibiod.2012. 05.018

Mathur, A., and Majumder, C. (2010). Kinetics modelling of the biodegradation of benzene, toluene and phenol as single substrate and mixed substrate by using Pseudomonas putida. Chem. Biochem. Eng. Q. 24, 101-109. doi: 10.15255/cabeq

Mohammadi, S., Kargari, A., Sanaeepur, H., Abbassian, K., Najafi, A., and Mofarrah, E. (2014). Phenol removal from industrial wastewaters: a short review. Desalin. Water Treat. 53, 2215-2234. doi: 10.1080/19443994.2014. 883327

Murinova, S., and Dercova, K. (2014). Response mechanisms of bacterial degraders to environmental contaminants on the level of cell walls and cytoplasmic membrane. Int. J. Microbiol. 2014:873081. doi: 10.1155/2014/873081

Nies, D. H. (1999). Microbial heavy-metal resistance. Appl. Microbiol. Biotechnol. 51, 730-750. doi: 10.1007/s002530051457

Ontanon, O. M., Gonzalez, P. S., and Agostini, E. (2015). Optimization of simultaneous removal of $\mathrm{Cr}(\mathrm{VI})$ and phenol by a native bacterial consortium: its use for bioaugmentation of co-polluted effluents. J. Appl. Microbiol. 119, 1011-1022. doi: 10.1111/jam.12913

Pal, B., Sarkar, P., and Pal, P. (2014). Isolation and characterization of phenol utilizing bacteria from industrial effluent-contaminated soil and kinetic evaluation of their biodegradation potential. J. Environ. Sci. Health A Tox. Hazard. Subst. Environ. Eng. 49, 67-77. doi: 10.1080/10934529.2013.824304

Prasse, C., Ford, B., Nomura, D. K., and Sedlak, D. L. (2018). Unexpected transformation of dissolved phenols to toxic dicarbonyls by hydroxyl radicals and UV light. Proc. Natl. Acad. Sci. U.S.A. 115, 2311-2316. doi: 10.1073/pnas. 1715821115

Rajasulochana, P., and Preethy, V. (2016). Comparison on efficiency of various techniques in treatment of waste and sewage water - A comprehensive review. Resour. Efficient Technol. 2, 175-184. doi: 10.1016/j.reffit.2016.09.004

Ramasamy, K., and Banu, S. P. (2007). "Bioremediation of metals: microbial processes and techniques," in Environmental Bioremediation Technologies, eds S. N. Singh, and R. D. Tripathi (Berlin: Springer), 173-187. doi: 10.1007/978-3540-34793-4_7

Reardon, K. F., Mosteller, D. C., and Bull Rogers, J. D. (2000). Biodegradation kinetics of benzene, toluene, and phenol as single and mixed substrates for Pseudomonas putida F1. Biotechnol. Bioeng. 69, 385-400. doi: 10.1002/10970290(20000820)69:4<385::aid-bit5>3.0.co;2-q

Sandhu, A., Halverson, L. J., and Beattie, G. A. (2009). Identification and genetic characterization of phenol-degrading bacteria from leaf microbial communities. Microb. Ecol. 57, 276-285. doi: 10.1007/s00248-008-9473-9

Sandrin, T. R., and Maier, R. M. (2003). Impact of metals on the biodegradation of organic pollutants. Environ. Health Perspect. 111, 1093-1101. doi: 10.1289/ehp. 5840

Satchanska, G., Topalova, Y., Dimkov, R., Groudeva, V., Petrov, P., Tsvetanov, C., et al. (2015). Phenol degradation by environmental bacteria entrapped in cryogels. Biotechnol. Biotechnol. Equip. 29, 514-521. doi: 10.1080/13102818. 2015.1009167

Sekar, J., Raju, K., Duraisamy, P., and Ramalingam Vaiyapuri, P. (2018). Potential of finger millet indigenous rhizobacterium Pseudomonas sp. MSSRFD41 in blast disease management-growth promotion and compatibility with the resident rhizomicrobiome. Front. Microbiol. 9:1029. doi: 10.3389/fmicb.2018. 01029

Shahryari, S., Zahiri, H. S., Haghbeen, K., Adrian, L., and Noghabi, K. A. (2018). High phenol degradation capacity of a newly characterized Acinetobacter sp. SA01: bacterial cell viability and membrane impairment in respect to the phenol 
toxicity. Ecotoxicol. Environ. Saf. 164, 455-466. doi: 10.1016/j.ecoenv.2018.08. 051

Shi, S., Qu, Y., Ma, F., and Zhou, J. (2014). Bioremediation of coking wastewater containing carbazole, dibenzofuran and dibenzothiophene by immobilized naphthalene-cultivated Arthrobacter sp. W1 in magnetic gellan gum. Bioresour. Technol. 166, 79-86. doi: 10.1016/j.biortech.2014.05.036

Silva, A. S., Camargo, F. A. D. O., Andreazza, R., Jacques, R. J. S., Baldoni, D. B., and Bento, F. M. (2012). Enzymatic activity of catechol 1, 2-dioxygenase and catechol 2, 3-dioxygenase produced by Gordonia polyisoprenivorans. Quim. Nova 35, 1587-1592. doi: 10.1590/s0100-40422012000800018

Thavamani, P., Megharaj, M., and Naidu, R. (2012). Bioremediation of high molecular weight polyaromatic hydrocarbons co-contaminated with metals in liquid and soil slurries by metal tolerant PAHs degrading bacterial consortium. Biodegradation 23, 823-835. doi: 10.1007/s10532-012-9572-7

Tian, M., Du, D., Zhou, W., Zeng, X., and Cheng, G. (2017). Phenol degradation and genotypic analysis of dioxygenase genes in bacteria isolated from sediments. Braz. J. Microbiol. 48, 305-313. doi: 10.1016/j.bjm.2016.12.002

Tiwari, J., Naoghare, P., Sivanesan, S., and Bafana, A. (2017). Biodegradation and detoxification of chloronitroaromatic pollutant by Cupriavidus. Bioresour. Technol. 223, 184-191. doi: 10.1016/j.biortech.2016.10.043

TRBA (2015). Classification of Prokaryotes (Bacteria and Archaea) into Risk Groups Committee on Biological Agents (ABAS). Available online at: https:// www.baua.de/EN/Tasks/Committee-administration/ABAS/ABAS_node.html (accessed June 6, 2017).

Tuan, N. N., Hsieh, H. C., Lin, Y. W., and Huang, S. L. (2011). Analysis of bacterial degradation pathways for long-chain alkylphenols involving phenol hydroxylase, alkylphenol monooxygenase and catechol dioxygenase genes. Bioresour. Technol. 102, 4232-4240. doi: 10.1016/j.biortech.2010. 12.067

Untergasser, A., Cutcutache, I., Koressaar, T., Ye, J., Faircloth, B. C., Remm, M., et al. (2012). Primer3-new capabilities and interfaces. Nucleic Acids Res. 40:e115. doi: 10.1093/nar/gks596

Vikram, S., Pandey, J., Kumar, S., and Raghava, G. P. (2013). Genes involved in degradation of para-nitrophenol are differentially arranged in form of noncontiguous gene clusters in Burkholderia sp. strain SJ98. PLoS One 8:e84766. doi: 10.1371/journal.pone.0084766

Villegas, L. G. C., Mashhadi, N., Chen, M., Mukherjee, D., Taylor, K. E., and Biswas, N. A. (2016). short review of techniques for phenol removal from wastewater. Curr. Pollut. Rep. 2, 157-167. doi: 10.1007/s40726-016-0035-3

Viswanath, G., Jegan, S., Baskaran, V., Kathiravan, R., and Prabavathy, V. R. (2015). Diversity and N-acyl-homoserine lactone production by Gammaproteobacteria associated with Avicennia marina rhizosphere of South Indian mangroves. Syst. Appl. Microbiol. 38, 340-345. doi: 10.1016/j.syapm.2015. 03.008

Wang, L., Li, Y., Yu, P., Xie, Z., Luo, Y., and Lin, Y. (2010). Biodegradation of phenol at high concentration by a novel fungal strain Paecilomyces variotii JH6. J. Hazard. Mater. 183, 366-371. doi: 10.1016/j.jhazmat.2010.07.033
Wang, P., Qu, Y., and Zhou, J. (2009). Biodegradation of mixed phenolic compounds under high salt conditions and salinity fluctuations by Arthrobacter sp. W1. Appl. Biochem. Biotechnol. 159, 623-633. doi: 10.1007/s12010-0088494-7

Wang, Y., Song, J., Zhao, W., He, X., Chen, J., and Xiao, M. (2011). In situ degradation of phenol and promotion of plant growth in contaminated environments by a single Pseudomonas aeruginosa strain. J. Hazard. Mater. 192, 354-360. doi: 10.1016/j.jhazmat.2011.05.031

Wang, Y., Wang, C., Li, A., and Gao, J. (2015). Biodegradation of pentachloronitrobenzene by Arthrobacter nicotianae DH19. Lett. Appl. Microbiol. 61, 403-410. doi: 10.1111/lam.12476

Westerberg, K., Elvang, A. M., Stackebrandt, E., and Jansson, J. K. (2000). Arthrobacter chlorophenolicus sp. nov., a new species capable of degrading high concentrations of 4-chlorophenol. Int. J. Syst. Evol. Microbiol. 50(Pt. 6), 2083-2092. doi: 10.1099/00207713-50-6-2083

Whiteley, A. S., Wiles, S., Lilley, A. K., Philp, J., and Bailey, M. J. (2001). Ecological and physiological analyses of Pseudomonad species within a phenol remediation system. J. Microbiol. Methods 44, 79-88. doi: 10.1016/s01677012(00)00231-1

Wong, K. K., Quilty, B., Hamzah, A., and Surif, S. (2015). Phenol biodegradation and metal removal by a mixed bacterial consortium. Bioremediat. J. 19, 104-112. doi: 10.1080/10889868.2014.995368

Wu, L., Ali, D. C., Liu, P., Peng, C., Zhai, J., Wang, Y., et al. (2018). Degradation of phenol via ortho-pathway by Kocuria sp. strain TIBETAN4 isolated from the soils around Qinghai Lake in China. PLoS One 13:e0199572. doi: 10.1371/ journal.pone.0199572

Yan, J., Jianping, W., Hongmei, L., Suliang, Y., and Zongding, H. (2005). The biodegradation of phenol at high initial concentration by the yeast Candida tropicalis. Biochem. Eng. J. 24, 243-247. doi: 10.1016/j.bej.2005.02.016

Yeom, S. H., and Yoo, Y. J. (1997). Overcoming the inhibition effects of metal ions in the degradation of benzene and toluene by Alcaligenes xylosoxidans y234. Korean J. Chem. Eng. 14, 204-208. doi: 10.1007/bf02706096

Zhai, Z., Wang, H., Yan, S., and Yao, J. (2012). Biodegradation of phenol at high concentration by a novel bacterium: Gulosibacter sp. YZ4. J. Chem. Technol. Biotechnol. 87, 105-111. doi: 10.1002/jctb.2689

Conflict of Interest: The authors declare that the research was conducted in the absence of any commercial or financial relationships that could be construed as a potential conflict of interest.

Copyright (c) 2020 Duraisamy, Sekar, Arunkumar and Ramalingam. This is an openaccess article distributed under the terms of the Creative Commons Attribution License (CC BY). The use, distribution or reproduction in other forums is permitted, provided the original author(s) and the copyright owner(s) are credited and that the original publication in this journal is cited, in accordance with accepted academic practice. No use, distribution or reproduction is permitted which does not comply with these terms. 